\title{
MALATYA GELENEKSEL COCUK OYUNLARI VE ÇOCUK GELIŞSIMINDE OYUNUN ROLÜ
}

\author{
Yasemin KATI*
}

Öz: Sözlü kültür ürünlerinden olan çocuk oyunları, ait oldukları kültürün geçmişinden bu gününe gelen, bu gününden de geleceğe aktarılacak en değerli kültür parçalarındandır.

Çalışmanın amacı, Malatya ilinde oynanan geleneksel çocuk oyunlarını geleceğe aktarmak, böylece bu ürünlerin kaybolup gitmesine engel olmaktır. Ayrıca bu oyunların, çocuk gelişimine etkisi üzerinde durmaktır.

Çalışma için saha araştırması, yazılı kaynaklardan yararlanma, gözlem, görüşme yoluyla derleme yapılmış, neticede Malatya ili merkezinde oynanan altmış yedi çocuk oyunu tespit edilmiştir. Çalışmada oyun kavramı, çocuk ve tespit edilen çocuk oyunları hakkında bilgiler verilmiş, oyunlar alfabetik sırayla aktarılmıştır.

Çocuk oyunlarının, çocuk gelişimindeki rolü hakkında değerlendirmeler yapılmış; oyunun çocuğun fiziksel, sosyal, kültürel, psikolojik, dil, zihin ve psiko-motor gelişimi açısından önemli rol oynadığı sonucuna varılmıştır.

Anahtar Kelimeler: Malatya, geleneksel, gelişim, çocuk, çocuk oyunları.

\section{MALATYA TRADITIONAL CHILD GAMES AND THE}

ROLE OF GAME IN CHILD'S DEVELOPMENTS

Abstract: Kid games which are the products of verbal culture are the most valuable elements of a culture. These games are transferred through generations.

The aim of the study is to transfer kid games which have been played in Malatya to future generations. In this way, we can prevent these products from disappearing. Besides, we would like to focus on the affects of kid games on development of kids.

For this study, we did field research, we benefited from written sources, we made observations, we collected information through interviews. As a result, we found out seven kid games which are played in city centre of Malatya. In this study, we explained the concept of game, we gave information about certain kid games and presented them alphabetically.

Assessments were made about the role of kid games on the development of kids. Finally, we discovered that games act an important part on the physical social, cultural, psychological, linguistic, intellectual and behavioral development of kids.

Key Words: Malatya, traditional, development, kid, kid games.

ORCID ID : 0000-0001-9244-8512

DOI : :10.31126-akrajournal.768232

Geliş tarihi : 11Temmuz 2020 / Kabul tarihi: 07 Eylül 2020

*Niğde Ömer Halisdemir Üniversitesi Sosyal Bilimler Enstitüsü Türk Dili ve Edebiyatı Ana Bilim Dalı Halk Edebiyatı Bilim Dalı. 


\section{Giriş}

Oyun kavramı, insanlığın tarihi kadar eskidir ve oyunlar hem yetişkinlere, hem de çocuklara hitap eder. Ancak oyun, çocukların dünyasında daha geniş ve derin yer tutar. Çocuk eğitimi açısından da oyunun yeri ve önemi inkâr edilemez. Her ne kadar günümüzde çocuk oyunları teknolojiye kurban verilmekte, çocuk teknolojiye esir olarak oyun oynamaktan geri dursa da, bu durum çocuğun eğitiminde oyunun önemini ve gerekliliğini azaltamaz. Çünkü çocuklar, oyunlar sayesinde topluma daha rahat ayak uydurur, sosyal varliklar olurlar. Fiziksel, kültürel, zihinsel, psikolojik, psiko-motor gelişim gibi birçok açıdan gelişirler.

Malatya ili merkezinde oynanan çocuk oyunları ve bu oyunların çocuğun eğitimine katkısı üzerine daha önce çalışma yapılmamış olması, bu çalışmayı gerekli kılmıştır.

$\mathrm{Bu}$ amaçla Malatya iline ait geleneksel çocuk oyunları derlenerek, bu oyunların eğitici yönü incelenmiştir. Ayrıca çocuk, oyun ve oyunun çocuk gelişimine etkisi üzerinde durulmuştur.

1.1. Çocuk: Bireyin hayatı; doğum öncesi, doğum esnası ve doğum sonrası olmak üzere dönemlere ayrılır bu dönemler de kendi içlerinde sınıflandırılabilir. Doğduktan sonra büyümeye başlayan birey, bebeklikten sonra çocukluk dönemini yaşar. Bu dönem, ergenliğe girene kadar devam eder. Çocuğun tanımı TDK sözlügünde şu şekildedir: “1. Küçük yaştaki oğlan veya kız. 2. Soy bakımından oğul veya kız evlat. 3. Bebeklik çă̆l ile ergenlik çă̆l arasındaki gelişme döneminde bulunan insan..." (TS, 1998: 495). Ferhan Oğuzkan çocuğu; “... iki yaşından, ergenlik çağına kadar süren büyüme dönemi içinde bulunan insan yavrusu veya henüz ergenlik dönemine erişmemiş kız veya erkek ..." (Oğuzkan, 2001: 2) olarak tanımlar. Tanımlara göre; küçük yaşta bulunan oğlan veya kız, bebeklik ve ergenlik çağı arasında bulunan insan, çocuk kabul edilmektedir.

1.2. Oyun: Oyun kavramı yetişkin veya çocuk, her bireyin dünyasında yer almaktadır. Oyunlar, kişilerin psikolojik ve sosyal açıdan gelişimine katkı sunarlar. Ancak her bireyin bir çocukluk evresi geçirdiği gerçeğinden hareketle denilebilir ki, oyun ve oyuncaklar öncelik ve özellikle çocukları ilgilendirir. Dolayısıyla oyun ve oyuncağın geçmişi, insanlık tarihi kadar eskiye dayanmaktadir.

Çocuk gerçeğinin var olmasından beri oyun kavramı da vardır. Tarih boyunca da çocuklar, kendilerini eğlendirecek bazı oyunlar oynamışlar, oyuncaklar edinmişlerdir. Çoğu zaman da oyunlarını kendileri icat etmişler, oyuncaklarını bireysel çabalarıyla yapmışlardır. Oyunlar ve oyuncaklar da geçmişten günümüze, zamanın şartlarına göre değişiklik göstererek gelmişler ve her dö- 
nem illaki çocuk dünyasında hak ettikleri yeri almışlardır. Türk Kil Kurumu'nun yayımladığı Türkçe Sözlük'te oyunun tanımı şu şekilde verilmiştir: "1. Vakit geçirmeye yarayan, belli kuralları olan eğlence." (TS, 1998: 1711). Oyun kavramı içerisinde, çocuk oyunlarının özel bir yeri vardır. Çünkü çocuk oyunları, çocuk gerçeğinin vaz geçilmezidir ve çocuğun gelişimini olumlu yönden etkileyen unsurlardır.

Çocuk oyunları sosyal ve teknolojik gelişmelere uyum sağlayarak değişikliklere uğrayabilirler. "Oyun kavramı içerisinde, çocuk oyunlarının özel bir yeri vardır. Oyun kavramı içerisinde geniş bir yer tutan çocuk oyunları, insanoğlunun dünyaya gelişinden itibaren başlamış, sosyal ve teknik gelişmelere göre kendini yenileyerek günümüze kadar gelmiştir. Yetişkinlerin birçok oyunu zamanla unutulduğu hâlde çocuk oyunları, çocukların oyun konusundaki tutuculukları, taşıyıcılıkları nedeniyle nesilden nesile aktarlmıştır." (Özhan, 1997: 4). Denilebilir ki çocuklar, oyunlarının unutulup gitmesine izni vermezler.

Oyun, çocuğun dünyasıdır ve çocuk için fizyolojik ihtiyaçları kadar önem arz eder. "Oyun; çocuğun yemek yemesi, uyuması, okulda ve evde ders saatleri dışında hemen hemen tüm yaşamını kapsar. Arkadaşı ile itişip kakışması, tek başına bahçenin bir başından bir başına koşması, merdivenden kayması birer oyundur." (Boratav, 2016: 267). Çocuklar, sosyal yaşamları içerisinde her eylemi kolayca oyuna çevirebilirler. "Oyun; çocuğun bedensel, ruhsal ve moral gelişimin sağlayan, haz ve neşe yaratan, tek ya da topluca yapılabilen etkinliktir." (Kantarcıoğlu, 1992: 74). Çocukların dünyasında, onların gelişimlerine katkı sunmalarının yanında oyunlar, bireysel ya da topluca yapılan eğlenceli aktivitelerdir.

Çocuklar oyun oynarken eğlenir, öğrenir, sosyalleşir ve gelişirler... "Oyunlar, kendini ifade etme, eğlenme, sosyalleşme, iç dünyayı yansıtma, gelişimi destekleme, ögrenme ortamı hazırlama, gizli enerjiyi kullanma ve hayal ile gerçeği ilişkilendirme gibi görevleri üstlenerek birey hayatında önemli bir yer edinir." (Uluğ, 2007: 12). Oyunlar, çocuğun enerjisini eğlenceye çevirerek olumlu kazanımlar edinmesini sağlar. Oyun esnasında hayal kuran çocuk, bu hayallerden yola çıkarak gerçek dünyayı daha iyi kavrar.

1.3. Oyunun, Çocuk Gelişimine Etkisi: Gelişim, bir bütün olarak organizmanın fiziksel olarak büyürken hem olgunlaşması hem de öğrenme ile bunları sentezleyip ilerlemesidir. Dünyaya yeni gelen her birey zamanla gelişip olgunlaşır.

Çocuk, yaşamı oyunla öğrenir, pekiştirir. Kısacası oyun, çocuk için yaşam demektir. "Oyun, yaşama sevincinin dişa vurulmasıdır. Oyun oynayamayan bir çocuk yaşamla bağını kesmiş sayılmalıdır, çünkü oyunda yaşamın özü, değişik biçimlerde canlanır ve anlam kazanır." (Nutku, 1998: 16). Çocuklar için 
oyunun pek çok faydası bulunmaktadır. Bunları şu şekilde sıralayabiliriz: Çocuklar, oyunlar vasıtasıyla kolayca eğitilebilir, hayata hazırlanabilir, karşılaşabilecekleri zorluklara karşı donanabilir, kriz yönetebilir, olumsuzlukların üstesinden gelebilmek açısından kendilerini yetiştirebilir, toplumsallaşır, sorumluluk alır, insani ve toplumsal değerler kazanır, zaman yönetimini öğrenebilir...

Toplum, gelişen bireylerin belli dönemlerde belli davranışları kazanmış olmasını ister. "Gelişimde, belli davranışların kazanılması gereken dönemler vardır. Illgili davranış ilgili dönemde kazanılmadı̆̆ı zaman, daha sonraki dönemlerde de kazanılamaz veya kazanılması çok zor olur." (Bacanl1, 2015: 51). Vaktinde edinilemeyen davranışları ilerleyen zaman dilimlerinde edinmek daha zor olacaktır.

"Oyun, altın çağına üç ve beş yaşları arasında ulaşır. Bu dönemi belirleyen özelliklerden biri, oyunun artık akranlar arasında oynanmasıdır. Üç yaşına dek çocuklar, ya yetişkinlerle ya da kendi başlarına oynarken, üç yaşından sonra yaşıtlarıyla oynamayı yeğlerler." (Göncü, 2005: 69). Oyuna "Hayır!" diyecek çocuk yoktur. Oyun; zorlama olmadan zevkle, keyifle oynanır.

Çocuğun fiziksel, sosyal, kültürel, psikolojik, dil, zihinsel gelişimi açısından oyun, çok ciddi bir önem taşır. Çünkü oyun, çocuğun gelişimini bu yönlerden etkiler ve geliştirir. Oyunun, çocuğun gelişim özellikleri üzerindeki etkilerini, ayrı başlıklar altında incelemek mümkündür. Konu şu alt başlık hâlinde ele alınabilir:

1.3.1. Oyunun, Çocuğun Fiziksel Gelişimine Etkisi: Çocuğun gelişimi üzerinde oyunun, olumlu etkisi oldukça fazladır. Örneğin oyun, çocuğun fiziki yapısının gelişmesini sağlar. Oyun oynayan çocuk; koşar, zıplar, atlar, yakalar, tutar, çeker... Kısacası vücuduna hareket yaptırmış olur. Bu hareketler, zaten sağlık için gereklidir. Çocuk oyun oynarken bu hareketleri ister istemez yapar. Hareketlerin gerçekleşmesi, vücut için spor anlamına gelmektedir. Çocuk hareket ettikçe vücut kasları harekete geçer ve bu durum; kas sisteminin, kemik ve eklemlerin gelişmesini sağlar.

Bir alandaki değişim ve gelişim, diğer alanları da ilgilendirir. "Fiziksel gelişim, beden ve fiziksel görünüşteki değişme kadar psiko- motor becerilerdeki gelişimi de kapsamaktadır." (Senemoğlu, 2009: 18). Fiziksel gelişimde oluşan sıkıntılar, ne yazık ki zihinsel ve duyusal gelişimi de etkiler.

Hareket eden çocuk, acıktığı için güzelce beslenir, beslenme neticesinde vücudu gelişir. Hareket etmesinden dolayı spor yapmış olduğu için sağlıkla büyür, fazla enerjisini harcadığı için düzenli şekilde uyku uyur. Oyunun bu faydalarından hareketle denilebilir ki oyun, çocuğun fiziksel gelişimi açısından çok önemli ve gereklidir. 
Derlenen oyunlar içerisinde; ayakta top oyunu, ayakla oynanması dolay1sıyla ayak ve bacakların gelişmesini sağlar. Bilek güreşi, kol ve bileğin hareketi bu organların gelişmesine katkı sunar. Çuval yarışı, özellikle bacakları geliştiren bir spor olduğu için bu organların gelişmesinde faydalıdır. Hana taşı, kendir çekme ve sülü değnek oyunlarında, ipi çekme veya taşları fırlatma dolayısıyla özellikle kol kaslarının gelişmesi hızlanır. Hümmeg, ip atlama ve uzun eşek oyunlarında oyuncuların, birbirlerinin ve ipin üzerinden atlamaları dolayısıyla ilgili organlar gelişir. Yakalamacılık, yakan top gibi oyunlar sayesinde de koşmak, hareket etmek durumunda olan oyuncuların, birçok vücut organının hareket etmesi dolayısıyla sağlık kazanmaları ve fiziksel olarak gelişmeleri mümkündür. Bu oyunların özellikle fiziksel gelişim açısından faydalı olacağı söylenebilir.

1.3.2. Oyunun, Çocuğun Sosyal Gelişimine Etkisi: Sosyal bir varlık olan insan, tabiatı gereği çevresiyle iletişim hâlinde ve bir topluma dâhil olmak mecburiyetindedir. Bir toplum içerisine yaşayan insanların ise, toplum kurallarına uyması gerekir, beklenir. Toplumun en küçük bireylerini ve o toplumun bir parçasını oluşturan çocuklar, ait oldukları toplumun birtakım kurallarını, oyunlar vasıtasıyla öğrenirler. Çünkü oynanan oyunun kurallarına, oyuncular tarafından uyulması gerekmektedir. "Birey içsel dünyası ile çevresi arasında bir uyum yakalamak için çabalar. Bireyin tüm çabası çevresine uyum sağlama içinde geçer. Bu uyum çabası doğumdan başlayarak bir gelişim göstermektedir. " (Yavuzer, 2000: 49). Uyum sağlamayan çocuk, oyun dışı bırakılır. Böylece çocuklar, yaşadıkları topluma ve toplum kurallarına, daha rahat uyum sağlamış olurlar.

Birbirleriyle iletişim hâlinde olan çocuklar, kuralları daha kolay kavramış olurlar. Böylece daha doğru ve sağlıklı iletişim kurarlar. Oyun içerisinde, üzerlerine düşen görevleri yerine getirdikleri için toplumda belli roller üstlenmiş olurlar ki bu duruma, sosyal öğrenme denilebilir. Oyundan gerekli hayat ve toplum derslerini alan çocuk; dostluk, yardımseverlik, dayanışma, paylaşımc1lık gibi özelliklerini geliştirmiştir. Bu gibi özellikleri gelişmiş olan bireyler, bulundukları ortamlarda gereken ilgi ve değeri edinmiş olacaklardır. Oyun ortamında gereğince ve yeterince bulunamamış çocuklar da yaşadıkları toplumda; hem çocukluk, hem de yetişkinlik dönemlerinde içine kapanık, öz güvenden yoksun, uyumsuz, mutsuz, istenmeyen bireyler olacaklardır. Demek ki bir çocuğun, yaşadığı toplumda olması gerektiği gibi yer alabilmesinde oyun, göz ardı edilemeyecek bir sosyal aktivite görevi üstlenmektedir.

Esasında en az iki kişiyle oynanan tüm oyunlar, çocuğun sosyalleşmesine katkı sağlayacaktır. Özelde belirtmek gerekirse de derlenen oyunlar içerisinde; genellikle kalabalık gruplar hâlinde ve açık alanlarda oynanan oyunlardan olan beş adım dur ve borik oyunları, ebe merkezli koşma, yakalama, ebeleme, el 
vurunca ebenin değişmesi gibi aktivitelere dayanmakta, bu oyunlar sayesinde yakın ve sıcak ilişki geliştiren oyuncuların sosyalleşmesine katkı sağlamaktadırlar. Ceviz dikme oyunu, ellerindeki cevizleri oyun aracı olarak ortaya koyan en az iki oyuncunun, oyun sayesinde daha sıcak ve samimi ilişki geliştirmelerini, oyuncuların sosyalleşmelerini sağlar. Sayısız oyuncunun oynadığı çuval yarış1, evcilik, hana taşı, hümmeg, kendir çekme, körebe, saklambaç, sülü değnek, uzun eşek, yakan top, yüzük...gibi oyunlar da yine oyuncu sayısı sınırsız olan oyunlardır. Oyuncu sayılarının fazla olması zaten, çocukların sosyal bir ortam içerisinde olmaları anlamına gelir. Bu ortam içerisinde kendisi yaşlarında ve benzer zevklere sahip başka çocuklarla muhatap olan, onlarla belli ilişkiler içerisine giren oyuncular da oyunlar sayesinde, sosyal açısından gelişme imkânı bulmuş olurlar.

1.3.3. Oyunun, Çocuğun Kültürel Gelişimine Etkisi: Her toplum kendine has kültürel değerlere sahiptir. Bu değerlerin, nesilden nesile aktarılmasında folklor ürünlerinin, önemli bir yeri vardır. Çocuk oyunları, folklor ürünlerindendir ve kültür aktarımında ciddi öneme sahiptir. "Oyun, bir ülkenin kültür zenginliğinin ifadesidir. Çünkü oyunlar, o ülke halkının sözlü edebiyatına, gelenek ve göreneklerine, müziğine, yaşam biçimlerine, çevreyle etkileşimlerini, inançlarını, kıyafet özelliklerini geleceğe en iyi şekilde aktarırlar." (Özhan, 1997: 6). Bu anlamda çocuk oyunları, iyi birer kültür taşıyıcısıdır. Geçmişten günümüze bünyesinde toplumun kültürel unsurlarını barındırırlar.

Oyunun çocuklar üzerindeki pek çok olumlu etkisi vardır. Bu etkilerden birisi de kültürel anlamdadır. Oyunlar, çocuğun kültürel anlamda gelişmesine katkı sunmaktadır. "Kültür, bir toplumun karakterini oluşturan, zaman içinde var ettiği değerler bütünüdür. Kültürel zenginlik ise o kültürü oluşturan unsurların çeşitliliğine ve ne kadar korunabildiğine bağlldır. Bu unsurlardan biri olan oyunlar, onlarl oynayanlar tarafindan bizzat korunmuş ve gelecek nesillere aktarılmıştır. " (Özbakır, 2009: 1). Çocuk, oyun oynadığı esnada, yaşadığ1 toplumun değerlerini öğrenir, kavrar, benimser. Sosyal hayatın içerisinde bu değerleri, yaşatmaya çalısıır, geleceğe aktarır.

Çocuk oyunları, iyi birer kültür taşıyıcılarıdır. Çocuklara kültür aktarımı yapıp, bilinç oluşturabilirler. Örneğin derlenen oyunlar içerisinde; cirit oyunu, ata sporlarımızdandır. Bu nedenle çok eski bir geçmişi vardır. Eski dönemlerden günümüze aktarılırken yanında kültür unsurlarımızı da taşır. Atalarımız için atın önemi çok büyüktür. Günümüzde at, eski önemini nispeten yitirmiştir. Sadece bu oyun vesilesiyle bile insanlar, atın kültürümüzdeki yerini kavrayabilir. Oyuncular, bu oyun vesilesi ile oyunun kuralları, atın önemi kültürümüzdeki yeri ve önemi hakkında bilgi sahibi olabilirler. Yine benzer şekilde çuval ve saklambaç oyunları da çok eski bir geçmişe sahip, kültürümüzü bu güne 
taşıyan oyunlarımızdandır. Bu açıdan çocuk oyunlarının, kültür aktarımı vazifesi gördükleri söylenebilir. Çocuğu bu anlamda geliştirebilirler.

1.3.4. Oyunun, Çocuğun Psikolojik Gelişimine Etkisi: Gülüp eğlenen, hoşça zaman geçiren bireylerin psikolojik açıdan iyi ve sağlıklı oldukları söylenebilir. Bu durum çocuklar için de geçerlidir. Oyun yoluyla kendisini mutlu ve eğlenceli bir ortamın içerisinde bulan, bu olumlu havayı teneffüs eden çocuğun, psikolojik açıdan rahatladığı ve zihinsel açıdan da tamamen, güzel düşüncelerle donandığı söylenebilir. Oyun; hayal dünyasında yaşayan çocuğun, hayaller ile gerçekleri ayırt edebilmesini sağlar. Çocuk hayatın bazı gerçeklerini, oyunun hayal dünyasında canlandırır ve kurguladığ 1 bu dünyanın içerisinde yaşar. "Çocuğun oyundaki hayal dünyası, onun gerçek yaşamı daha iyi görmesini ve kavramasını sağlayarak psikolojik olgunluğuna yardımcı olur." (Özhan, 1997: 23). Oyunlar, çocukları gerçek yaşama hazırlamanın yanında, psikolojik açıdan donanmalarına da yardım ederler.

Gerçek yaşamı ilk olarak oyun ortamında canlandıran, yaşayan çocuklar; ilerleyen yaşlarında hayatın gerçekleriyle yüz yüze geldiklerinde, hazırlıklı olmuş olurlar. Karşılaştıkları olumsuzluklarla daha kolay baş ederler. Bu da onların, hayatları boyunca psikolojik açıdan sağlıklı bireyler olmalarına yardımcı olur.

Tüm oyunlar, çocuk üzerinde güzel bir psikolojik etkiye sahiptirler. Çocuğun daha iyi hissetmesini sağlarlar. Çocuk oyunlarının genel olarak hepsi, çocuğun psikolojisi açısından terapi görevi görür. Özelde ise derlenen oyunlar içerisinde; çöp çekme, körebe, saklambaç... gibi oyunların çocuğun psikolojisinin düzgün tutulması açısından yardımcı olacakları söylenebilir. Mesela çöp çekme oyununda kısa çöpü çekmeyi isteyen çocuk, bu durumun heyecanını kendi dünyasında fazlasıyla yaşar. Kısa çöpün kendisine çıkmaması durumunda, şansını başka sefere deneyecek, kazandığı durumda ise fazlasıyla mutlu olacaktır. Körebe ve saklambaç oyunlarında da yine ebe tarafindan yakalanma heyecanını sürekli bir şekilde canlı tutan çocuklar, bu heyecana eş değer şekilde oyun ortamında mutluluklar da yaşayacaklardır. Yakalanmamaları durumunda ise başarı kazandıkları için psikolojik açıdan iyi hissedeceklerdir. Oyunlar sonunda elde edilen tüm başarılar zaten, çocukları psikolojik olarak fazlasiyla memnun eder.

1.3.5. Oyunun, Çocuğun Dil Gelişimine Etkisi: Bir iletişim aracı olan dil, sosyal hayat içerisinde yer alan tüm insanlar için kendilerini ifade etme, toplumda daha etkin bireyler olmalarını sağlama açısından çok önemli bir vasıtadır. En etkili iletişim araçlarındandır. Dil vasıtasıyla insanlar, toplum içerisinde daha etkili bir varlık gösterirler. Dil sayesinde insan kendisini, dış dünyaya ifade eder. 
Çocuk; korku, kayg1, üzüntü, sevinç, heyecan, istek, hayal ve düşüncelerini dil sayesinde en iyi, net ve doğru şekilde iletir dış dünyaya. Böylece zorlu yaşam koşullarını kendi lehine çevirir ve hayatını kolaylaştırmış olur. Bu nedenle dil öğrenmek birey açısından çok önemli ve gereklidir. Aynı zamanda zorunluluktur. "Oyun, çocuklarda ifade edebilme, anlatma gelişimine de büyük katkl sağlar." (Gül, 2012: 40). Çocuğun konuşarak kendini ifade edebilmesi ona özgüven duygusu kazandıracaktır.

Dil eğitimi, çok erken yaşlarda başlar. Çocuk da en verimli dil eğitimini sosyal ortamlarda alır. Aile ve arkadaş ortamları bu anlamla çok önemli görevler üstlenirler. Arkadaş ortamında alınacak dil eğitimi açısından çocuk oyunları, önemli bir araç olarak karşımıza çıkar. "Ana dili öğretimi/öğrenimi sürecinde eğitsel oyunlar sayesinde öncelikle kaygl, çekingenlik, özgüven eksikliği gibi olumsuz özelliklerin öğrenme ortamından çekilmesi sağlanır. Duyusal açıdan ögrencilerin dil ögrenme sürecine etki eden oyunlar, ayn zamanda dilsel, bilişsel ve sosyal gelişimlerine de katkıda bulunur. Öğrencilere iletişim temelli, temel dil becerilerini geliştirebileceği öğrenme ortamlart sunar. Bu ortamlarda akranlarıyla etkileşim içerisinde bulunan ögrrenciler anlamlı bir bağlam içerisinde ana dilini kullanma ve zihinsel becerilerini geliştirme firsatı bulur." (Erol, 2019: 50-51). Oyun ortamı, çocuğun ana dilini öğrenmesinde ona kolaylıklar sağlar. Çocuklar, bu esnada iletişim içerisinde olurlar konuşurlar, dinlerler. Oyun esnasında söylenen tekerlemeler ve şarkılar sayesinde, dillerini ve kelime hazinelerini geliştirirler. Neticede, kendilerine hayatları boyunca gerekli olacak bir iletişim aracı olan dili de öğrenmiş/ kavramış olurlar.

Özellikle içerisinde sayışmaca, tekerleme, söylenmesi gereken cümleler barındıran oyunlar, dil gelişimine yardım eden oyunlardır. Örneğin derlenen oyunlar içerisinde; aç kapıyı bezirgân başı oyunu, "Aç kapıyı bezirgân başı. Kapı hakkı ne alırsın, ne verirsin. Bir sıçan, iki sıçan üç sıçan, deliğe kaçan." şeklinde ezgi ve sayışmaca eşliğinde oynanan bir oyundur. Bu tarz ezgi ve sayışmaca eşliğinde oynanan oyunlar, dilin maharetini gerektirdiği için dilin gelişmesine de katkı sağlar. Zira bu gibi oyunlarda dili, seri ve kusursuz kullanmak gerekmektedir.

Aldım verdim oyununda, "Aldım, verdim; ben, seni, yendim." cümlesinin art arda ve yanlışsız söylenmesi gerekir. El el epenek oyununda, "El el epenek, elden çıkan kepenek, kepeneğin yarısı, yumurtanın sarısı, yağa batır, bala batır, sen yemezsen bana getir." cümleleri, oyuncuların dil gelişimine katkı sağlayacak öneme sahiptir. Yağ satarım bal satarım oyunu esnasında söylenen, "Yağ satarım, bal satarım, ustam ölmüş ben satarım. Ustamın kürkü sarıdır. Satsam otuz liradır. Zambak, zumbak arkana, önüne iyi bak.” Tekerlemesinin de yine, dil gelişimine olumlu yönde etki edeceği, çocuğun dil gelişimine katkı sunacağı söylenebilir. 
1.3.6. Oyunun, Çocuğun Zihinsel Gelişimine Etkisi: İnsanın; düşünen, akleden bir varlık olması onu, diğer canlılardan ayıran özelliklerdendir. Zekâ, doğuştan getirilen bazı kalıtsal özelliklerden etkilendiği gibi, yaşamın ilk yıllarında da geliştirilebilir. Çocuk oyunlarının, çocukların zihinsel gelişimlerine olumlu anlamda katkısı vardır. "Bireyin çevresindeki dünyayı anlama ve öğrenmesini sağlayan, aktif zihinsel faaliyetlerdeki gelişime bilişsel gelişim adı verilmektedir. " (Senemoğlu, 2009: 32). Bilişsel açıdan gelişen çocuk, yaşadığı dünyayı daha iyi anlar ve öğrenir.

Oyunlar çocuğun; düşünce gücünü, üretkenliğini ve problem çözme yeteneğini geliştirebilir. Bu doğrultuda, tamamen zihinle alakalı oyunlar da vardır. $\mathrm{Bu}$ oyunlar sayesinde, çocuğun zihnine yerleşmesi istenenler, oyun yoluyla çok daha kolay yerleşir. Kalıcı duruma gelebilir.

Özellikle zekâ oyunları başlığı altında zikredilen oyunlar, çocukların zihinsel gelişimine katkı sağlarlar. Derlenen oyunlar içerisinde; deve- cüce oyununda, yanarak oyun dışı kalmamak için çok hızlı düşünmek ve hareket etmek gerekmektedir. Çünkü düşünülmeden yapılacak en küçük hamle, oyun dışı kalmaya sebep olacaktır. Dokuztaş ve üçtaş oyunları zaten, tamamen zekâya dayalı oyunlardır. Rakip oyuncuyu yenebilmek için ince ve teferruatlı düşünmek ona göre hamleler yapmak gerekmektedir. Kibrit oyununda, mantıklı ve hedefe odaklı hareket etmek, kibriti ona göre atmak gerekmektedir. Düşünülmeden yapılacak atışlar, oyunu diğer oyuncunun kazanmasına neden olacaktır. Bende değil onda ve yüzük oyunlarında da ebenin, taşı verdiği kişiyi doğru tahmin etmek ve fincan altındaki yüzügü bulmak dikkat ve yoğunlaşma isteyen birer eylemdir. Bu açılardan özellikle bu oyunların, çocuğun zihinsel gelişimi açısından faydalı olacakları söylenebilir.

1.3.7. Oyunun, Çocuğun Psiko- Motor Gelişimine Etkisi: Psiko-motor gelişim, fiziksel büyüme ve merkezi sinir sisteminin gelişimine paralel olarak organizmanın isteme bağlı hareketlilik kazanmasıdır. Bir başka deyişle, temelinde hareket olan becerilerin kazanılmasını içeren ve doğum öncesi dönemde başlayıp ömür boyu süren bir süreçtir. Bu sürecin başarılı bir şekilde gelişmesi ve ilerlemesinde, oyunların rolü çok fazladır. Çocuğun bu becerileri, oyun ortamında gelişir ve güçlenir. Tutma, çekme, koparma, koşma, yürüme, atlama, firlatma... büyük ve küçük kaslarını kullanma gibi yetenekleri gelişir.

Bazı oyunları oynamak için yapılanlar, çocukta kasları ve el göz koordinasyonunu geliştirir. “Özellikle, su, kil, çamur, kum, plastilin, parmak boyası ile oynama; katlama, kesme, yapıştırma, bağlama, ilikleme, çözme, dikme, çizme, boyama gibi etkinlikler çocukta küçük kasların motor gelişimin yanı sıra elgöz koordinasyonunu da saglar." (Doğan, 2010: 44). Bazı oyunların malzemeleri de çocuğun gelişimine katkı sunar. 
Psiko-motor gelişim, bedensel gelişme ile paralellik göstermektedir. "Çocuğun kol ve bacaklart ile tüm organların kullanmada güç ve hız kazanmasina, beden organları arasında eşgüdüm sağlanmasina ve onları denetim altına almada becerikli duruma gelmesine devimsel gelişim, psiko - motor gelişim denir. Bu gelişme bedensel gelişmeye paralel olarak oluşur ve kişinin çevresine uyum yapmasınt sağlar. Bireyin bir bütün olarak gelişmesinde önemli rol oynar." (Yeşilyaprak, 2006: 57). Psiko-motor gelişimin sağlanması için fiziksel gelişimin de olması gerekmektedir. Bu anlamda fiziksel gelişime etki eden tüm oyunlar, psiko-motor gelişim için de yararlı olacaktır.

Genel olarak çocuk oyunları, çocukların psiko-motor gelişimlerine katkı sağlar. Aynı zamanda bu oyunların, çocuklar tarafından güzel ve olması gerektiği şekilde oynanabilmeleri için de çocuğun, psiko-motor açıdan gelişiminin iyi olması gerekmektedir. Derlediğimiz oyunlar içerisinde; asker paşa, aşık, beş taş, bilye, ceviz dikme, çember çevirme, develeme, kaşıkta yumurta taşıma, kibrit kutusu, yazı-tura, yedi tuğla, zeytin çekirdeği... gibi oyunların hepsi belli bir psiko-motor gelişim olgunluğuna sahip çocuklar tarafindan, daha başarılı şekilde oynanacak oyunlar içerisindedirler. Aynı zamanda da çocuğun, bu yönde gelişimine katkı sağlayacakları belirtilebilir. Aşık, bilye, ceviz dikme, yedi tuğla ve zeytin çekirdeği oyunlarının başarıyla oynanabilmesi için hedefe kusursuz atışların gerçekleşmesi gerekmektedir. Develeme, çember çevirme, kaşıkta yumurta taşıyabilmek için de el, kol, göz koordinasyonunun iyi sağlanması, dolayısıyla yine psiko-motor gelişimin yeterince olması gerekmektedir.

\section{Malatya İli Merkezinde}

\section{Oynanan Geleneksel Çocuk Oyunları}

Malatya'da kaynak şahıslar arasında yapılan derlemeler sonucunda, kendi çocukluk dönemlerinde oynadıkları oyunlar tespit edilmiş, kaynak şahıslar anlatırken bu oyunlar kayda alınıp sonradan yazıya aktarılıış̧ır. Ayrıca gözlem yapılarak ve yazılı kaynaklardan da yararlanılarak Malatya ili merkezinde toplam, altmış yedi oyun türü tespit edilmiştir.

Aşağıda, derlenen altmış yedi oyun örneğine yer verilmiştir. Söz konusu oyunların yerel isimleri değiştirilmemiş olup günümüze kadar gelen oyunlar ve aldıkları güncel isimler belirtilmiştir.

2.1. Aç Kapıyı Bezirgân Başı: En en az dört kişi ile oynanır. İki kişi ebe olur, diğer kişiler oyuncu olurlar. Ebe olan oyuncular karşılıklı dururlar.

Kollarını birbirine bağlarlar. Kapı gibi durur, dışarıdakinin içeri girmesini önlemeye çalışırlar. Diğer oyuncular, aradan geçmeye çalışırlar. Ebe olan oyuncular, önceden kendi aralarında gizlice iki meyve ismi tutarlar. Bu meyveler genelde elma ve kayısı olur. Dışarıdaki oyuncular, "Aç kapıyı bezirgân başı. 
Kapı hakkı ne alırsın, ne verirsin. Bir sıçan, iki sıçan üç sıçan, deliğe kaçan.” derler. Ebe olan oyuncuların, ellerinin altından geçmeye çalışırlar. Deliğe kaçan dedikten sonra, ebe olan oyuncu ellerinin altında geçen oyuncuyu yakalar.

Daha sonra önceden belirledikleri meyvenin ismini söylerler. Yakalanan oyuncu birini seçer. Yakalanan oyuncunun seçtiği meyve, ebelerden hangisine aitse oyuncu o ebenin arkasına geçer aynı şekilde diğer oyuncular da seçilir. Seçilme işi bittikten sonra, çizgi çizilir. Ebeler, çizginin iki tarafına geçer. Ebelerin oyuncuları da, ebelerin arkasına geçerek birbirlerini çizginin diğer tarafina çekmeye çalışırlar. Hangi grup diğer grubu çekerse o grup oyunu kazanmış olur $(\mathrm{KK}: 1,10)$.

2.2. Aldım Verdim Oyunu: $\mathrm{Bu}$ oyun, ebe belirlemek için oynanan bir oyundur. Oyuncular belli mesafede karşı karşıya geçerler. İlk oyuncu, bir ayağının topuğunu, diğer ayağının parmak uçlarına değdirerek adım sayarken her adımına bir kelime gelecek şekilde "Aldım, verdim, ben, seni, yendim." der ve sözü bitince bekler. Sıra, diğer oyuncuya geçer. Diger oyuncu da aynı şekilde 'adım, verdim...' sayar. Oyunculardan hangisinin ayağ 1 önce diğer oyuncunun ayağının üzerine gelirse, o oyuncu kazanmış olur. Kaybeden oyuncu ise diğer oyuncuyla aynı şekilde yapmaya devam eder. En sona kalan oyuncu, mağlup, dolayısıyla ebe olmuş olur (KK: 3 ).

2.3. Asker- Paşa Oyunu: Oyun genellikle iki kişiyle, evin içerisinde oynanır. Kibrit kutusunun; dik gelen kısmına 'paşa', yan gelen kısmına 'asker' denir. Düz geldiği zaman oyuncu, diğer oyuncuya kibrit kutusunu verir. Puanlama yapılır. Askerin puanı daha azdır. Paşanın puanı askerin puanının iki katıdır. Hedeflenen puanı kazanan, oyunu da kazanmış olur (KK: 2, 3) .

2.4. Aşık Oyunu: Aşık, çift tırnaklı hayvanların ön dizlerinde bulunan mafsal kemiğine verilen addır. Dört tarafı vardır. Oyun oynamaya elverişlidir. Genellikle koyun kemiğiyle oynanır. Aşık kemiği, elin baş, işaret ve orta parmaklarıyla tutulur. Belli bir yükseklikten bırakılır. Yere düşen kemiğin, şekline göre çeşitli adlandırmalar yapılır. Kemiğin enli tarafından çukur olan kısmı yukarıda kalırsa 'Aç'; karsı tarafı yukarıda kalırsa 'Tok'; dar ve düzce olan iki yüzünden kenarı hafifçe kalkık ve ortası çukurca olan kısmı yukarıda ise 'Bey', bunun karşı tarafı yukarda ise 'Kıt' adını alır. Oyuncular sırasıyla bu kemiği, belirli bir yükseklikten aşağı atarlar. 'Bey' gelen oyuncu kazanır (KK: 2, 3, 4).

2.5. Atçılık Oyunu: Atçılık oyunu, açık alanlarda oynanan bir oyundur. Oyun için iki-üç metre uzunluğunda bir odun parçası ve yine elli santimetre civarlarında kısa bir ince çubuk gereklidir. Çocuklar, uzun değneği bacaklarının arasına alıp santimetrelik çubuğu da kamçı niyetine kullanarak onunla koşar, eğlenirler. En hızlı koşan birinci olur (KK: 6, 8). 
2.6. Ayakta Top Oyunu: Oyuna başlamadan önce hayvan kıllarından, bez parçalarından, deri parçalarından, hayvan yününden, saç kıllarından vs. bir top yapılır. Oyuncular, ayakta çember oluşturacak şekilde dizilirler. Oyuna başlayan oyuncu, topu eline alır ve herhangi bir oyuncunun üzerine atar. Kendisine top atılan oyuncu, topu yakalarsa o da diğer oyunculardan birisine atar. Eğer topu yakalayamazsa oyundan elenir ve topu atan oyuncu, topu yine alır ve arkadaşlarına atar. Oyun, tek kişi kalıncaya kadar devam eder (KK: 1, $2,3,6,7)$.

2.7. Bende Değil Onda Oyunu: Oyuncular ayakta çember şeklinde dururlar. Durdukları yerin yaklaşık yirmi metre ilerisine bir çember çizilir. Her oyuncunun bir numarası vardır ve ebenin elinde küçük bir taş vardır. Ebe, elindeki taşı birine gizlice verir. Ebeden taşı istediklerinde ebe, "Bende değil yedide." Yedi numaralı oyuncu, "Bende değil üçte." Şeklinde devam eder. Kişi, taşı birine vermeden yakalanırsa diğer oyuncular tarafından kovalanır çemberin içine giren oyuncuya dokunulmaz. Oyun baştan başlayarak devam eder (KK: 8).

2.8. Beş Adım Dur Oyunu: Genel olarak kalabalık gruplar ile açık alanlarda oynanan bir oyundur. Kurayla bir ebe seçilir ve ebe, otuza kadar sayar. $\mathrm{Bu}$ esnada tüm oyuncular, ebeden uzaklaşır. Ebe, koşarak bir oyuncuya doğru yaklaşır ve "Beş adım dur." der. Tüm oyuncular durur. Ebe olan oyuncu, beş adım sayıp kovaladığı en yakın oyuncunun ayağına değerse veya ona kavuşursa ebe o kişi olur. Eğer değemezse ebe olan oyuncu ebeliğe devam eder (KK: 8, 10).

2.9. Beş Taş Oyunu: Çok eskiden beri oynanan bir oyundur. Kişi sayısı sınırlı değildir. Tek kişi dahi oynayabilir. Ancak sıranın çebucak gelmesi için oyuncu sayısı sınırlı tutulabilir. Daha çok, kız çocuklarının oynadığı bir oyundur. Oyuna başlamadan önce yuvarlak, hepsi aynı anda tek ele sığacak büyüklükte beş adet taş toplanır ve daire şeklinde oturulur. Yarışmaya ilk olarak kimin başlayacağı; avuç içine saklanan taşların tek mi, çift mi olduğu sorusuna verilen cevaplar doğrultusunda belirlenir.

Oyuna başlama hakkı elde eden oyuncu, avucuna beş taşı alır ve önüne atar. Yerdeki bu beş taşın içerisinden birini alır ve tek eliyle havaya attıktan sonra yine aynı eliyle yerden bir taş alıp aynı anda da havaya attığ maya çalısır. Havaya tekrar taş atar ve yerdeki taşların hepsini bu şekilde toplar. Daha sonraki aşamada taşları, ikiser ikiser toplar. Sonra havaya attıgı taşı düşürmeden yerdeki taşın üçünü birden alır ve diğerini tek alır. Elindeki taşlardan birini havaya atar ve diğer taşları düşürmeden yere koyar. Elindeki taşı tekrar havaya atar ve dört taşı yerden alır. Taşlar avucunda iken taşın birini havaya atar ve "Bal parmak" diyerek işaret parmağını yere değdirir ve taşı tekrar yere düşürmeden yakalar. 
Oyuncu bütün taşları yere atar. Taşlardan birini eline aldıktan sonra diğer elinin baş ve işaret parmağıyla taşların yakınında köprü pozisyonu alır. Diğer oyunculardan birisi "Bu benim itim." diyerek taşlardan birini sahiplenir. Artık bu taşa değdirilmeden diğer taşlar, köprünün altından, taşın birisi havaya atıldığı esnada sırasıyla geçirilecektir. En son, diğer oyuncunun seçtigi taş geçirilir. Eğer taş, yandan dışarı giderse oyuncu yanmış olur.

Bütün taşları kuralına uygun şekilde geçiren oyuncu, taşları iki avucuna alıp havaya atar ve bitiştirdiği ellerinin üst tarafında onları tutmaya çalışır. Sonra tekrar havaya atar ve bu sefer de avuç içiyle tutar. Taşların hepsini tutamazsa yanar. Son olarak oyuncu, taşları tek eline alıp havaya atar ve tek elinin tersiyle tutmaya çalışır. Kaç taş tuttuysa ona göre taş başına ikişer puan verilir. Önceden belirlenen sayıya ulaşan oyuncu, oyunu kazanmış olur (KK: 9).

2.10. Bilek Güreşi Oyunu: Oyuncular genelde masada veya sıranın üstünde, kollarını paralel olarak birbirlerine uzatıp dirseklerini yere koyarak birbirlerinin ellerini tutarlar. Sikıca kavranan bileklerden, hangisi yere önce vurulursa o, oyunu kaybeder diğeri kazanmış olur (KK: 7).

2.11. Bilye Vurma Oyunu: Açık alanlarda, bilyelerle oynanan bir oyundur. Oyun için cam veya taş bilyeler kullanılır. Oyuna başlamadan önce sıralama belirlenir. Oyuncular, birbirlerinden uzaklaşırlar ve bilyelerini yere bırakırlar. İlk sırada olan oyuncu, yerdeki bilyelerden istediğini vurmak üzere harekete geçer. Bunun için bilyesini eline alır ve elini yere yakın tutar. Bazen, elini yere koyarak yerden destek aldığı da olur. Bu şekilde, hedefindeki bilyeyi daha rahat vurabilecektir. Bilyeyi, parmaklarının arasına sıkıştırarak sıkar. Eğer vuramazsa, ikinci olan oyuncu oynamaya başlar. Oyuncular, vurdukları bilyeleri alırlar. En çok bilye alan, oyunun galibidir. Yerde bilye kalmadığınde oyuncular isterlerse oyun, aynı sırayla devam eder (KK: 1, 2, 5).

2.12. Borik Oyunu Dişarıda oynanan bu oyun için öncelikle bir daire çizilir. $\mathrm{O}$ dairenin dışına yine bir daire çizilir. İçerideki dairenin içine bir kişi girer ve başına, bir mendil veya bir bez parçası konulur. Diğer oyuncular, ikinci dairenin içerisinden dışarı çıkamaz. Oyuncular, ebenin kafasındaki mendili almaya çalışırlar. Ebe, kendi çizgisinden çıkmadan oyunculardan herhangi birine dokunduğu zaman, dokunduğu oyuncu ebe olur (KK: 7).

2.13. Buzda Kayma: Kış aylarında, kız ve erkek çocuklarının oynadığı bir oyundur. Oyuncular, belirlenen buzlu alana bir çizgi çizerler ve bu çizginin gerisinden koşup çizgiyi geçmeden kayarak en uzak mesafeye gitmeye çalışırlar. Oyuncular, çizginin gerisinden kayabilirler ama çizgiyi geçtikten sonra kayarlarsa hata yapmış olurlar. En uzak mesafeye kayan oyuncu, oyunu kazanır (KK: 6). 
2.14. Ceviz Dikme Oyunu I: Düz bir çizgi çizilir. Oyuncular sırayla bu çizgiye ikişer ceviz dizerler. Yaklaşık beş metre uzaklıktan, başka bir cevizle ve sırayla bu cevizleri vurmaya çalışırlar. Sağ veya sol baş diye isimlendirilir. Cevizin sağ tarafına yani sağ başına vuran, cevizin tümünü alır. Sol tarafına vuran da cevizin tümünü alır. Ortalarda duran cevizi vuran, vurduğu cevizin sol tarafındakileri alır, sağ taraftakiler kalır. Oyun böyle devam eder (KK: 3 ).

2.15. Ceviz Dikme Oyunu II: Genelde iki kişi tarafından oynanır. Birinci kişi cevizini ortaya atar, diğeri o cevizi vurmaya çalışır. Vuramazsa sıra diğer oyuncuya geçer. Diğer oyuncu aynı şekilde cevizi vurmaya çalışır. Cevizi vuran oyuncu, cevizi kazanmış olur (KK: 3).

2.16. Cirit Oyunu: Cirit oyunu, açık alanda oynanan bir oyundur. Oyuna başlamadan önce oyuncular, bir metre kadar uzunluğunda, düzgün birer ağaç parçası bulurlar. Genellikle cirit yapımında, düz olmasından dolayı söğüt ağacı kullanılır. Oyuna başlamadan once, bir atış çizgisi çizilir. Oyuncular atış yaparken bu çizgiyi geçemezler. Ciridi en uzağa atan oyuncu, yarışmayı kazanır. Bu oyun, ata sporumuz olan ciritle karıştırılmamalıdır. Oynayış açısından iki oyun, birbiriyle farklılık göstermektedir (KK: 3).

2.17: Çatılı Hombek (Güvercin Taklası): Çatılı hombek oyunu, en az sekiz kişiyle açık alanda oynanır. Oyuncular iki grup olur. Kura ile ebe takımı seçerler. Ebe takımın iki oyuncusu birbirine dönerek dururlar. Öbür takımın iki oyuncunun birisi arka tarafa, diğeri ön tarafa dönerler ve kafalarını, birbirlerine dönük vaziyette duran arkadaşlarının bacaklarının arasına sokarlar. Diğer takımın oyuncuları, eğilmiş vaziyette duran oyuncuların üzerinden takla atarak karşı tarafa düşerler. Oyuncular takla atarken diğer oyuncular, engelleyici hareket yapamazlar. Oyunculardan birisi, takla atamazsa diğer oyuncular geçerler. Oyun bu şekilde devam eder (KK: 9).

2.18: Çember Çevirme: Daha çok erkek çocuklar arasında oynanan bir oyundur. Genellikle otomobil lastiklerinin ağılarındaki çelik teller çıkarılır ve çember olarak kullanılır. Bazen de göbeği ve telleri çıkarılmış bisiklet cantı, çember olarak kullanılır. Ya da bu oyun için satılan çemberler kullanılabilir. Çember sürmek için belirli bir kalınlıkta, çember teli denilen ve çemberin sürülmesini sağlayan bir itme çubuğu yapılır.

Çembere yön, sürücüsü tarafindan verilir. Çemberi çevirmek tamamen oyuncunun yeteneğine bağlıdır. Oyuncular düz bir alanda yan yana dizilirler. Kendilerine bir hedef belirlerler. Başlama komutuyla oyuncular çemberlerini sürmeye başlarlar. Belirlenen mesafeye ilk önce varan oyuncu, yarışmayı kazanmış olur (KK: 9, 10).

2.19. Çöp Çekme Oyunu: Çöp çekme oyunu, ebe belirleme oyunu olarak da bilinir. Oyunculardan birisi, oyuncu sayısına göre eline ince çöplerden alır. Çöpler, eşit büyüklükte seçilir. Çöplerden bir tanesi, diğerlerinden kısa olacak 
şekilde kırılır. Bir oyuncu, çöpleri parmakların arasına yerleştirir ve oyunculara birer tane çektirir. Hangi oyuncu kısa çöpü çekerse, o oyuncu ebe olur. Çöpleri tutan oyuncu, çöpü tuttuğu için çekilişe katılamaz $(\mathrm{KK}: 1,2)$.

2.20. Çuval Yarışı Oyunu: Çuval yarışı oyunu, açık alanlarda oynanan bir oyundur. Oyuncular oyuna başlamadan once, birer adet çuval alırlar. Oyunculardan bir tanesi hakem olur. Bir çizgi çizilir. Bu çizgiye, başlama çizgisi denir. Çizginin 30 metre kadar karşısına da bir varış çizgisi çizilir. Oyuna katılacak oyuncular, ellerindeki çuvalın içine girerler. Çuvalın ağzını sıkıca tutarlar. Hakem, "Başla!" komutunu verdiği zaman oyuncular, varış çizgisine ulaşmak için zıplayarak mücadele ederler. Çizgiye ilk varan oyuncu, birinci olur. Oyunda, sıçramak önemlidir. İyi sıçrayan oyuncu, varış çizgisine erken ulaşır. Oyuncular, yarış esnasında genelde düşerler ama yeniden kalkar ve mücadeleye devam ederler (KK: 2, 3, 8, 10).

2.21. Deve Cüce Oyunu: Bu oyun, gruplar hâlinde oynanır. Oyuncular s1raya dizilirler. Bir kişi oyunu oynatır. Oyun oynatan kişi, "Deve" deyince tüm grup ayağa kalkar. "Cüce" deyince herkes oturur. Şaşırtmalı bir şekilde, rastgele söylenen deve, cüce talimatlarına uyamayan, geç kalan veya yanlış hareket eden oyundan çıkar. Oyun, tek kişi kalana kadar devam eder. En son kalan kazanandir (KK: 7).

2.22. Develeme (Kökleme) Oyunu: Kökleme oyunu, develeme ile oynanan bir oyundur. Oyuna başlamadan önce oyuncular, develemelerine ipi sararlar. Kura çekerler, kurayı kaybeden oyuncu develemesini yere bırakır. Diğer oyuncu, yerdeki develemeyi kendi develemesiyle vurmaya çalışır. Develemeyi vurursa vurduğu develemeyi kazanmış olur. Vuramazsa develemesini yere bırakır. Diğer oyunculardan birisi atar. Oyunda iple develemenin atılmasına "kökleme" denir. Develeme oyununda oldugu gibi dönme gerektirmediginden kökleme oyunu, her yerde oynanabilir (KK: 9).

2.23. Develeme (Topaç) Oyunu: Kenarları renk renk boyalı develemeler alınır. Sert ağaçlardan yapılan develemelerin ucuna, sivri bir çivi çakılır. Takılan çividen başlanarak çivinin etrafından ip döndürülerek develemenin üzeri, iple sarılır. Diğer oyuncular da develemelerini aynı şekilde sararlar. Sarılan develemeler hep birlikte yere atılır. Atılma anına çok dikkat edilir. Sonra atan olursa oyun, geçersiz sayılır ve yeniden atılır.

Oyunda önemli olan, develemenin dönme süresidir. Develemesi en fazla dönen oyuncu, oyunu kazanır ve rakibinin develemesini alır. Develemenin dönme esnasında oyuncular; "Benimki seninkini yutuyor." derler. Bu işte usta olanlar, develeme yerde dönerken onu ellerine alıp avuçlarında dönmesini sağlarlar. Develeme, buzda iyi döndüğünden, genellikle kışın oynanır. Özellikle erkek çocukları tarafından çok sevilen bir oyundur (KK: 6). 
2.24. Dokuz Taş Oyunu: Dokuz taş oyunu; zihni geliş̧iren, dikkati artıran ve iki kişi arasında oynanan bir oyundur. Oyuncular, oyuna başlamadan önce düz bir tahta, taş veya zemin üzerine şekli çizerler. Şekil çizildikten sonra oyunculardan her birisi, dokuzar tane rakibinin taşına karışmayacak türden ufak taş alırlar. Taşları aldıktan sonra, şekildeki çizgilerin birleştigi yerlere sırasıyla taşları birer birer dizerler. Kurayı kazanan oyuncu, tahtaya ilk taşı koyarak oyuna başlar. Sonra rakip oyuncu tahtaya bir taş koyar. Her iki oyuncu da, elindeki dokuz taş bitinceye kadar taşları oyun tahtası üzerine sırayla koyarlar. Bu sırada oyunculardan herhangi biri yatay ya da dikey olarak taşlarını üç taş yapmışsa rakibinin bir taşını tahtadan alır ve onu oyun dışı bırakır. Rakibin üç taşı varsa üçlü bozulmaz. Üçlü olmayanlardan birisi alınır. Ancak üç taş yapılmış olanlardan başka taş yoksa üçlüyü bozarak bir taş alır.

Çapraz üç taş yapılamaz. Oyuncular ellerindeki dokuz taşı da oyun tahtasına bırakmaları gerekmektedir. Aksi takdirde, tahtada hiç bir taşı yerinden oynatamazlar. Yani hamle yapamazlar. Çizgilerin kesiştiği noktalara bırakılan taşlar ancak çizginin doğrultusunda hareket ettirilebilir. Üç taşı aynı hizada, fakat ayrı noktada olan oyuncu oyunu kazanır. Oyunculardan herhangi birisi taşlarını, dokuz taş şeması üzerinde hareket ettiremezse oyunda yenik sayılır (KK: 4).

2.25. Duvara Vurma Oyunu: Duvara vurma oyunu, açı alanlarda oynanan bir oyundur. Oyuncular, oyuna başlamadan önce duvara yuvarlak bir şekil çizerler. Kura ile sıralama belirlenir. İlk oyuncu, elindeki bilyeyi duvara çizilen çizginin içine değecek şekilde vurur. İkinci oyuncu da aynı şekilde, duvara bilyesini vurur. Ĕger ilk bilyeye değerse o bilyeyi alır. Yeniden kendi bilyesini eline alır ve bilyesini duvara vurur. Üçüncü oyuncu da aynı şekilde bilyesini atar ve yerdeki bilyeye vuramadığı zaman, dördüncü oyuncu bilyesini atar. O da vuramazsa, ilk oyuncu bilyesini duvara vurarak yerdeki bilyeleri vurmaya çalışır. Yerdeki bilyelerden birisini vurdugu zaman, bilyelerin hepsini alır. Oyun bu şekilde devam eder (KK: 5).

2.26. Duvarda Saydırmaca Oyunu: Duvarda saydırmaca oyunu, kıl veya bez topla oynanan bir oyundur. Oyuncular oyuna başlamadan önce toplanırlar ve ulaşılması gereken sayıyı belirlerler. Oyuna ilk başlayan oyuncu, topu eline alır ve duvarda saydırmaya başlar. Saydırmaya başlandığında topu, yakalama veya düşürme olursa sıra, diğer oyuncuya geçer. $O$ da aynı şekilde saydırır. Oyun basında belirlenen sayıya ilk önce ulaşan oyuncu, o oyunu kazanır (KK: $1,3)$.

2.27. Ebe Çıkarma Oyunu: Toprakta sabit, gömülü bir taş vardır. Oyuncular, gözlerine kestirdikleri bu taşı ebe olarak kabul ederler ve onu topraktan çıkarmak için oyun kurarlar. Oyuncuların her biri, bu taşın etrafına halka şeklinde birer çukur kazarlar. Eşit sayıdaki bilyelerini, belli bir uzaklıktan sıra 
ile kendi çukurlarına atmaya çalışırlar. Kuyuya giren her bilye için ebenin etrafını kazma hakkı elde edilir. Ebe yani taş, bulunduğu yerden çıkana kadar oyun devam eder. Ebeyi, en fazla emek harcayarak çıkaran oyuncu, birinci olmuş olur (KK: 5).

2.28. El El Epenek Oyunu: Her ortamda oynanabilen bir oyundur. Oyuncular, yuvarlak şekilde, birbirlerine çok yakın otururlar. Avuç içleri yere gelecek şekilde, ellerini yere bırakırlar. Ebe olan oyuncu, tek elini yere bırakır ve diğer eliyle oyuncuların eline dokunarak "El el epenek, elden çıkan kepenek, kepeneğin yarısı, yumurtanın sarısı, yağa batır, bala batır, sen yemezsen bana getir." tekerlemesini söyler. Bu esnada da elini diğer oyuncaların ellerinin üzerinde dolaştırır. Tekerleme, hangi oyuncunun elinin üzerinde son bulursa o oyuncunun eli, oyun dişı kalır. Oyun dışı olan oyuncu, elini koltuğunun altına koyar. Ebe olan oyuncu, aynı tekerlemeyi Söylemeye devam eder. Oyuncuların hepsi çıkana kadar oyuna bu şekilde devam edilir (KK: 6, 7).

2.29. Elde Saydırmaca: Açık ve kapalı alanlarda oynanan bir oyundur. Oyuncular kıldan, kağıttan veya bez parçalarından yapılmış bir topla bu oyunu oynarlar. Sonraları plastik toplarla oynanmıştır. Oyunun başında herhangi bir sayı belirlenir. Topu saydırmaya başlayan oyuncu, topu havaya atar ve tutmadan ona vurarak saymaya başlar. Sayan oyuncu topu düşürürse sıra diğer oyuncuya geçer. Oyunun başında belirlenen sayıya ilk ulaşan oyuncu, birinci olur (KK: 10).

2.30. Eski Minder Oyunu: Çocuklar, halka şeklini alarak eski minder tekerlemesini söylerler. Böylece eski minder seçilen, yani ebe olan çocuğun etrafında dönerler. Tekerleme şöyledir: "Eski minder, yüzünü göster, göstermezsen bir poz ver. Güzellik mi, çirkinlik mi, havuz başında heykellik mi, mankenlik mi, hangisi?" Tekerleme bitince oyuncular, eski minder olan oyuncunun istediği pozu verirler. Eski minder de en beğendiği pozu seçer. Pozu beğenilen çocuk, eski minder olur $(\mathrm{KK}: 8,9)$.

2.31. Evcilik Oyunu: Evcilik oyunu; kışın evlerde, yazın bahçelerde açık alanlarda, kısacası yer ortamda oynanan bir oyundur. Özellikle kız çocukları oynamaktadır. Oyunda oyuncular, istedikleri rolleri alırlar. Oyun malzemeleri, oyuncular tarafindan hazırlanır. Bu malzemeler, mutfaktan alınan kimi malzemeler olabileceği gibi hamurdan, çamurdan bezlerden yapılan oyun malzemeleri de olabilir. Örneğin oyuncular; bezden yaptıkları bebekleri, topraktan yaptıkları kab kaçakları, ağaçtan yaptıkları çatal, kaşığı kullanabilirler. Oyunda her oyuncu; anne, baba, çocuk, abla...gibi rollere girerler (KK: 2).

2.32. Gazoz Kapağı Oyunu: Oyun, en az iki kişiyle oynanır. Oyuncular, öncelikle gazoz kapakları biriktirir. Gazoz kapakları her oyuncu için eşit sayıda 
yan yana dizilir. Yaklaşık dört beş metre uzağa bir çizgi çizilir. Çizginin arkasından ellik adı verilen oval bir taşla bu kapaklar nişan alınır. Her oyuncu sırayla taşı atar. Kapağa vuran oyuncu eğer sağ baştaki kapağa vurmuş ise kapakların hepsini, ortadakilere vurmuş ise vurduğu kapağın solundakilerin hepsini alır. En fazla kapak alan, oyunu kazanır (KK: 1, 6, 8).

2.33. Hana/Hane Taşı (Dikili Taş) Oyunu: Dikili taş oyunu, açık alanlarda oynanan bir oyundur. Oyuncular, oyuna başlamadan önce yumruk büyüklüğünde birer tane yuvarlak taş bulurlar. Bir çizgi ile belirledikleri yere, yaklasık on metre uzaklıkta olmak üzere ve ileriye doğru, oyuncu sayısına göre $15 \mathrm{~cm}$ arayla taşları tek tek dizerler. Oyuncu sıralaması kurayla belirlenir. İlk oyuncu, belirlenen çizgiden dizili taşlara doğru elindeki taşı firlatır. Taşlardan birini vurduğu zaman, çizgiye gelir ve yine firlatır. Vuramazsa sıra, ikinci oyuncuya geçer. O da, aynı şekilde atar. Sıralama, bu şekilde devam eder. Taşların hepsi vurulduğu zaman, en fazla taş vuran oyuncu, birinci olur. Eşitlik durumunda, yeniden yarışma yapılır (KK: 5).

2.34. Hümmeg (Birdir Bir) Oyunu: Açık alanlarda oynanan bir oyundur. İki kişi veya iki ekip tarafından oynanır. Ekipler arasında kura çekilir. Bunlar arasından bir kişi, elini diz kapaklarına koyarak eğilir. Diğeri de bu oyuncunun üzerinden "Hümmeg" diyerek atlar. Her atlayıştan sonra eğilmiş durumda olan oyuncu, belini yavaş yavaş yükseltir. Bu durum, diğer oyuncunun atlayamayacağı yüksekliğe gelinceye kadar devam eder. Eğilen oyuncunun üzerinden atlayamayan oyuncu ile diğer oyuncu yer değiştirirler.

Oyunun kurallarına göre eğilen oyuncunun sırtına yalnız, atlayan oyuncunun eli değebilir. Ya da oyun, eğilen oyuncunun hiçbir yerine, atlayan oyuncunun değmemesi üzerine kurulabilir. Bunlar, oyunun başında oyuncuların, kendi aralarında fikir birliğine varmalarıyla belirlenen kurallardır. Oyuncuların, hiçbir yerlerinin değmemesi üzerine anlaşmalarıyla oynanan hümmeg oyunu esnasında oyuncular, "Kirli mirli değmesin, hümmegggg!." diye bağırarak atlar.

"Hümmeg" oyununda ikinci bir şekil ise, atlama anında üflenerek uzağa düşürme çabasının gösterilmesidir. Oyunun galibi, bu cismi en uzağa düşürme becerini gösteren oyuncudur (Doğan, 2010: 85).

2.35. İp Atlama I: Bu oyun, tek oyuncuyla oynanır. Aynı oyunu oynamay1 düşünenler, sırasını bekler. Oyuncular, yaşlarına uygun uzunluktaki bir ipin iki ucundan tutarak kafalarının üzerinden geçirip üstünden atlamak suretiyle oyunu oynarlar. İp atlayan oyuncu, bir şekilde atlayamadığında sıra, diğer oyuncuya geçer. Her atlayışta sayı sayılır. En fazla atlayan oyuncu birinci olur. Eskiden ipin pek fazla bulunmadığı zaman dilimlerine kızlar, saç örgülerini kesip birbirlerine ekleyip örmek suretiyle istedikleri kalınlıkta ipler elde ederler ve bu iplerle ip oyunlarını oynarlarmış (KK: 7). 
2.36. İp Atlama II: Bu oyunda oyuncu sayısı sınırsızdır. Uzun bir ipin iki ucundan, iki kişi tutar. Diğer oyuncular da atlamak amacıyla sıraya geçerler. İpin ucundan tutanlar, ipi sallamaya başlarlar. Sıradaki oyuncular da sırayla sallanan ipin üzerinden belli sayıda atlarlar. Bazen ikişer, üçer oyuncunun oyuna girdiği de olur. Atlama sayısını tamamlayan, sıranın en arkasına geçer ve tekrar sıraya girmiş olur. Atlama sayısını tamamlayamadan yananlar ise ipin ucundan tutup sallama görevini üstlenirler. Böylece ipin ucunu tutanlar da, oyuna dâhil olmuş olurlar. Atlama işlemi, tek ayak veya çift ayakla yapılabilir (KK: 7).

2.37. İstop Oyunu: İstop oyunu, açık alanlarda topla oynanan bir oyundur. Oyunda genellikle, kıl ve bez toplar kullanılır. Oyun başlamadan oyuncular, kura ile bir ebe belirlerler. Ebe, çember şeklini alan oyuncuların ortasına geçer. Ebenin, topu havaya atması ve oyunculardan birinin ismini söylemesiyle oyun başlar. İsmi söylenen oyuncu, topu havadayken yakalamaya çalışır. yakalayana kadar diger oyuncular oldukları yerden uzaklasırlar. İsmi söylenen oyuncu, topu yere düsürmeden yakalarsa bağırarak "İstop" der. İstop dendigi anda, kaçan diğ er oyuncular, oldukları yerde kalırlar. Ebe olan oyuncu, topu yakaladığ yerden, diğer oyunculardan birisine vurmaya topla çalışır. Eğer oyunculardan birisini vuramazsa tekrar ebe olur.

Ebenin topla vurmayı başardığı oyuncu ise yeni ebedir. Bu sefer yeni ebe, topu havaya atar. Diğer oyunculardan birisinin ismini söyler. Oyunda çabukluk çok önemlidir. Eskiden topun pek fazla bulunamadığı zamanlarda aileler, kestikleri horozun kursağını şişirmek suretiyle çocuklarına top yaparlarmış. Bazen de top, hayvan kıllarından ve yünlerinden, eski giysilerden veya kağıttan yapılırmış (KK: 9).

2.38. Jandarma- Kaçak Oyunu: Oyuna başlamadan önce, oyunculardan birisi ebe olur. Diğer oyuncular, ebe olan oyuncunun etrafında toplanırlar ve sıraya geçerler. Sırası gelen oyuncu, ebeye kolunu uzatır. Ebe olan oyuncu, kolunu uzatan oyuncunun parmak uçlarından tutar. Avuç içini, diğer oyuncunun elinin üzerine kor ve "jandarma" der. Sonra yan tarafına, elinin diş yüzeyini koyar ve "kaçak" der. Ebe olan oyuncu, diğer oyuncunun omuz hizasına kadar eliyle bu şekilde çıkar. Omuz hizasına geldiğinde en son jandarma gelirse, oyuncu jandarma olur. Kaçak gelirse kaçak olur.

Ebe, oyuncuların hepsini bu şekilde ayırır. Sonra jandarma gelen oyuncular, kaçak gelen oyuncuları kovalar, kaçaklar da zaten kaçar. Jandarmalar yakaladıkları kaçakları, ebenin çizdiği çemberin içine bırakırlar. Çemberin dışında kalan kaçaklar, jandarmaya yakalanmadan kaledeki oyunculara dokunurlarsa kaledeki kaçaklar kurtulur. Kaçakların hepsi yakalandıgı zaman bu sefer oyun tam tersine döner. Yani jandarmalar kaçak, kaçaklar jandarma olur. Oyun bu şekilde devam eder (KK: 1, 6). 
2.39 Karga Oyunu: Açık alanlarda oynanan bir oyundur. Oyuncular, oyuna başlamadan önce bir yere toplanırlar. Oyuna başlama komutu geldikten sonra birbirlerini yakalamaya çalışırlar. Yakalanan oyuncunun, kafasına bastırılır ve "Gak gak..." denilerek vurulur. Oyun, yakalanan oyuncunun kaçmasına kadar böyle devam eder. Bu oyunda güçlü olmak önemlidir. Çünkü güçlü olan oyuncu diğerlerini daha rahat döver (KK: 5).

2.40. Kaşıkta Yumurta Taşıma Yarışı: Kaşıkta yumurta taşıma yarışı, açık alanlarda oynanan bir oyundur. Oyuncuların her biri, bir kaşık ve bir yumurta alır. Bu yumurtalar, düşme tehlikelerine karşın genellikle haşlanırlar. Çünkü düşüp de kırıldığı takdirde, yarışmacı tarafından atılmayıp afiyetle yenecektir. Yarışmanın yapılabilmesi için düz bir çizgi çizilir. Yarışmacılar, bu çizgi üzerinde dizilirler. Kaşı̆̆ın sapını ağızlarında tutar, yumurtayı da kaşığa yerleştirirler. Hakemin, "Başla!" komutu ile beraber oyuncular, yumurtalarını düşürmeden belirlenen hedefe doğru koşarlar. Yumurtasını düşüren oyuncu, oyundan elenir. Belirlenen hedefe, ilk varan oyuncu ise yarışmanın galibidir (KK: 3, 4, 6, 7, 10).

2.41. Kendir Çekme Oyunu: Genellikle yaz mevsiminde ve açık alanlarda, en az iki kişiyle oynanan bir oyundur. Oyuncu sayısı sınırsızdır, ne kadar artarsa oyun, o kadar güzel ve zevkli olur. Oyuncular, belirli bir mesafede karşılıklı iki eşit gruba ayrılırlar. Bir hakem belirlenir. İki grubun arasına, bir çizgi çizilir ve ortaya, belirli uzunlukta bir ip bırakılır. İki grubun oyuncuları, ipten tutarlar ve hakemin komutuyla karş1lıkl çekmeye başlarlar. Rakibini, ortadaki çizgiyi geçene kadar kendine dogru çekmeyi başaran grup, oyunu kazanır. Bu oyunda her şeyin eşit şekilde ayarlanması gerekir. Oyuncu sayısı, çizgi mesafesi, ipin tam ortasından iki grubun eline verilmesi gibi. Aksi takdirde yenilen grup, sonuca itiraz edecektir (KK: 1, 6, 7, 9).

2.42. Kibrit Kutusu Oyunu I: Kibrit oyunu, düz olan her zeminde oynanabilen bir oyundur. Özellikle ev ortamında oynanmaya çok uygundur. Oyun, kibrit kutusu ile oynandığından bu ismi almıştır. En az dört kişiyle oynanan bir oyundur. Oyuna ilk başlayan oyuncu, kibrit kutusunu atar. Kutu dik gelirse hâkim, yarı dik gelirse jandarma, yatay şekilli taraf gelirse geçersiz, yatay şekilsiz taraf gelirse ebe olur. Oyuna başlamadan hâkim gelene kadar oyuncular kibriti sırasıyla atarlar. Hakim ilk gelen, oyuna ilk başlayacak olandır. Oyun sıralaması belirlendikten sonra oyuncular kibrit kutusunu atarak oyuna başlarlar. Kendisine jandarma gelen oyuncu, hâkime sorar; "Hâkim Bey, kaç tane vuralım?" Hâkimin söylediği sayı kadar jandarma, ebeye vurur. Vurma işlemi elle, küçük bir odun parçası veya havluyla gerçekleştirilir. Oyun, bu şekilde devam eder (KK: 2, 3). 
2.43. Kibrit Kutusu Oyunu II: Kibrit kutusu oyunu, düz olan her zeminde oynanabilir. Özellikle ev ortamında oynanmaya çok uygundur. Oyun, kibrit kutusu ile oynandığından bu ismi almıştır. En az iki kişiyle oynanan bir oyundur. Kutunun her kenarı, oyun başlamadan puanlaştırılır. Kutunun kenarlarından dik olan kısmın puanı, en yüksektir. Yarı dik kısımlar daha az puanlı, yatay taraflar ise daha az ve eşit puanlıdır. Oyuna ilk başlayan oyuncu, kibrit kutusunu atar. Kendisine gelen kısma göre puanlarını biriktirmeye başlar. Hedeflenen puana ilk ulaşan oyuncu galip olandır (KK: 2, 3).

2.44. Kim Vurdu Oyunu: Bu oyun açık alanlarda, en az beş altı kişilik gruplarla oynanır. Bir ebe seçilir. Bir kişi de ebenin yanında durur. Ebe, kafasını yanında duran oyuncunun dizlerinin üzerine koyar. Diğer oyunculardan biri, ebeye görünmeden onun sırtına vurur. Ebenin, dizine başını koyduğu oyuncu, ebeye kimin vurmuş olabileceğini sorar. Ebe, diğer oyuncular arasında kendisine vuranı bulabilirse ebelikten kurtulur. Eğer yanlış cevap verirse ebeliği devam eder (KK: 1$)$.

2.45. Körebe Oyunu: Açık alanlarda oynanan bir oyundur. Oyuncu sayısı isteğe bağlıdır. Oyuncular, oyuna başlamadan önce ebe seçimi yaparlar. Ebe olan oyuncunun gözü, mendil veya herhangi bir bez parçası ile bağlanır. Gözleri bağlı olan oyuncu, diger oyuncuları yakalamaya çalışır. Diğer oyuncular, ebeye ses verirler. Ebe olan oyuncu, sesin geldiği yere doğru hareket eder. Oyuncuları yakalamaya çalışır. Diğer oyuncular ebeye vururlar. Ebe kendisine yaklaşan oyuncuları yakalamaya çalışır. Yakaladığı oyuncu, ebe olur. Yakalanan oyuncunun gözleri başlanır. Oyun bu şekilde devam eder $(\mathrm{KK}: 7,8)$.

2.46. Köşe Kapmaca Oyunu: Köşe kapma oyunu, kapalı ve açık alanlarda, evlerin avlusunda, odalarda, çizgiyle belirlenmiş alanlarda vs. en az üç kisiyle oynanan bir oyundur. Oyuna başlamadan önce ebe belirlenir. Ebe, belirlenen alanın ortasında durur. Diğer oyuncular köşelere geçerler. Oyuncu köşedeyken ebe, köşeye yaklaşmaz. Ebe görmeden oyuncular birbirleriyle işaretleşirler ve köşelerini değiştirirler. Eğer ebe, boş kalan bir köşeyi kaparsa ortada kalan oyuncu ebe olur. Oyun bu şekilde devam eder (KK: 6).

2.47. Kuş Oyunu: İki oyuncunun oynadığı bir oyundur. Oyuncular toprağın yüzeyinde kendi önlerinde yan yana, aynı zamanda da rakibin kuyularının karşısına altışar çukur açarlar. Bu oyun, dört çukur açmak suretiyle de oynanabilir. Her oyuncunun dörder çukuru varsa, on altışar da taşları olur. Yani her çukura dörder taş yerleştirirler. Oyuna ilk başlayan kişi, Çukurun birindeki kendi taşlarını alır ve her çukura birer tane bırakacak şekilde dağıtır. Diğer oyuncu da aynı eylemi tekrarlar. Bu taş yerleştirme esnasında kendi çukurunda bir taş brakmayı başaran oyuncu, karşısındaki diğer oyuncunun çukurunda bulunan bütün taşları almaya hak kazanır. Rakibin taşlarını toplamayı başaran oyuncu kazanır. Oyunu kazanan, kuş olmuş olur (KK: 2). 
2.48. Kutu Kutu Pense Oyunu: Oyun en az üç kişi ile oynanır. Oyuncular, oyun için el ele tutuşarak halka yaparlar. Halkayı bozmadan, el ele tutuşmuşşekilde dönen oyuncular aynı zamanda, "Kutu kutu pense, elmamı yerse, arkadaşım Berat, arkasını dönse." şarkısını söylerler. Oyuncuların isim söylemesinden sonra, ismi okunan kişi arkasını döner. Bu şekilde devam eden oyunda oyuncuların hepsi, arkasını dönmüş bir şekilde dönerken ikinci aşamada tekrar isimler söylenir. Bu sefer de, "Kutu kutu pense, elmamı yerse, arkadaşım Berat, önünü dönse." denir. İsmi söylenen oyuncular sırayla önlerini dönmüş bir şekilde dönmeye devam ederler. Oyun böylece devam edip gider (KK: 1, 4).

2.49. Mendil Kapmaca Oyunu: Mendil kapma oyunu, açık alanlarda oynanan bir oyundur. Ebe, mendili tutan kişidir. Oyuna başlamadan önce oyuncular, ebe olur. Yirmi metre mesafede karşıllıklı iki çizgi çizilir. Ebe olan oyuncu, iki çizginin ortasında durur ve eline, bir mendil veya bez parçası alır. İki grup, karşılıklı olarak çizgilere dizilirler. 'Başla' komutundan sonra iki oyuncu, karşılıklı çizgilerden çıkarak ebenin iki tarafında dururlar ve elindeki mendili kapmaya çalışırlar. Mendili kapan oyuncu, diğer oyuncuya vurulmadan kendi çizgisine gelirse diğer oyuncuyu elemiş olur.

Diğer oyuncu ise elenmemek için mendili kapan oyuncu kendi sınır çizgisine gelmeden önce ona, eliyle dokunmak mecburiyetindedir. Eğer dokunamazsa kendisi elenmiş̧ olur. Elenen oyuncular, oyunun dışına çıkar ve elenmeyen

oyuncular sirasiyla oyuna devam ederler. Bir gruptaki tüm oyuncular elenene kadar oyun devam eder. Tüm oyuncuları elenen grup, yenilmiş olur (KK: $8)$.

2.50. Onda Bunda Oyunu: Günümüzde hâlâ oynanmakta olan bir oyundur. Genellikle iki kişi ile oynanır. Oyunculardan birisi, ellerini arkasına götürerek diğer oyuncuya göstermeden bir avcunun içine, bir taş alır ve iki elini de kapatarak ellerini, diğer oyuncunun önüne uzatır. Diğer oyuncu, elle-rini uzatan oyuncunun, kapalı olan ellerinin birinden başlayarak parmağıyla "Elle, gülle, rrbık, lülle bunda" şeklinde veya farklı bir sayışmaca ile sayma-ya başlar. Sayma işlemi bittikten sonra parmak hangi eli gösteriyorsa onu tercih etmiş demektir. Oyuncu, o elini açar. Diğer oyuncu, taşı bulursa oyunu kazanmış olur. Taş oyuncunun gösterdiği elde değilse, oyunu kaybeder. Bazen de sayışmaca olmadan bir el işaret edilerek tahminde bulunulur (KK: 5).

2.51. Parmak Güreşi Oyunu: İki oyuncu ile oynanan bir oyundur. Oyuncular, sağ ellerinin parmaklarını birbirine geçirirler. Baş parmaklar havada durur. Ellerini birbirinden çözmeden baş parmaklarıyla rakibin baş parmağını yakalamaya çalışırlar (KK: 7). 
2.52. Saklambaç Oyunu: Oyuncular oyuna başlamadan önce bir ebe seçerler. Ebe belirlendikten sonra duvara, bir yuvarlak çizgi çizilir. Çizilen bu alan, kale olur. Ebe olan oyuncu elini kaleye koyar, kafasını da elinin üzerine bırakır. Birden otuza kadar yavaş yavaş sayar ve "Arkama, önüme saklanan ebe, sobe" der. Sayma işlemi bittikten sonra, kaleden uzaklaşmadan diğer oyuncuları aramaya başlar. Oyunculardan birini gördügü zaman, oyuncunun ismini söyler ve koşarak kaleye elini vurur. "Sobe!" der. Gördüğü oyuncu, ebeden once gelip elini kaleye vurduğu zaman ebe yeniden otuza kadar sayar. Diğer oyuncular saklanır.

Ebe, oyuncunun ismini söyleyip elini kaleye vurduğu zaman o oyuncu, yanmış olur. Ebe, tüm oyuncuları bu şekilde yakarsa, ilk oyun disı olan oyuncu ebe olur. Ebe dört oyuncuyu yakıp, bir oyuncu ebeden önce kaleye geldigi zaman, yanan oyuncuları kurtarmış olur. Ebe, otuza kadar saydığında diğer oyuncular da saklanır. Oyun, bu şekilde devam eder (KK: 7, 9).

2.53. Sapan Atma Oyunu: Çocukların çok sevdiği oyunlardan biridir. Ağaçların ' $y$ ' şeklinde olan kısımları kesilir. Eczanelerde, sağlık ocaklarında serum hortumları veya daha eskiden, giysiler için kullanılan normal lastiğin uçlarına deri parçası takılır. Bu deri parçası, taç konulup atılacak parçadır. Diğer uçlar, 'y' şeklindeki ağaç parçasına bağlanır. Deri kısmın içerisine taş konularak bir hedefe doğru atılır. Oyunlar içerisinde istenmeyen kazalara en fazla sebebiyet veren oyun budur (KK: 3, 5, 6).

2.54. Sek Sek (Çizgi Taşı) Oyunu: Oyun, yere çizilen belirli bir şekil üzerinde, özellikle kız çocukları tarafından oynanır. Sek sek oyunu, el büyüklüğündeki yassı bir taşla oynanır. Çizginin her karesine birden başlanarak sırayla sayı verilir. Toplam sekiz kare vardır. Belirlenen ilk oyuncu, çizginin ilk karesinin içerisine, elindeki taşı atar. Tek ayak üzerinde sekerek şekillerin içinden geçer. Sadece yan yana olan 3-4 ve 7-8. sayılarda iki ayağını da indirir. Tüm kutuların içine basarak geçer, dönüp geldiğinde attığı taşını alır. Di-ğer sefere bir sonraki kutunun içine atar. Çizgi üzerine attığı taşı getirmeden, çizgilere basmadan oynanan bir oyundur (KK: 3 ).

2.55. Sülü Değnek Oyunu: Çelik çomak oyununa Malatya'da bu isim verilir. En az iki kişi tarafından oynanır. Dayanıklı bir ağaçtan biri kısa, digeri uzun iki değnek kesilir. Kısa değnek, sülü ismiyle anılır. Kadı taşı kabul edilen iki taş ile ocak kurulur. Sülü, bu kadı taşlarının üzerine orta kısmı boşa gelecek şekilde yatırılır. Oyuncu, elindeki değnekle sülüyü biraz havalandırdıktan sonra ikinci hamlesini yapar. Havalanan sülüye elindeki değnekle vurarak en uzak mesafeye atmaya çalışır.

Beceri isteyen bir oyundur. Tarafların ilk oynama hakkı, kura ile veya belirli bir mesafenin değnekle ölçülmesi şeklinde tespit edilir. Oyuncu tarafından atılan sülü, alta kalan takım ekiplerince havadan yakalanmaya çalışılır. Sülü, 
havada iken tutulursa, ekipler oyunda yer değiş̧irmiş olur. Tutulamazsa sülü, düştüğü mesafeden bir oyuncu tarafından kadı taşlarına doğru atılır. Kadı taşlarını bekleyen oyuncu ise elindeki değnekle kadısını korur. Atılan sülüyü elindeki değnekle vurmak suretiyle uzaklaştırmaya çalışır. Sülü, kadı taşlarına çok yakın düşmüş ve arada bir değneklik mesafe kalmışsa oyuncu, oynama hakkını kaybeder. Oyun hakkı, oyun ekibinden başka bir kişiye geçer. Bu durum, aynı şekilde devam ederek ekipteki oyuncu sayısı bitinceye kadar sürer.

Oyundaki birinci atışa düz atış denir. İkinci atış, oynayan oyuncunun bacaklarını ayırarak değneği, bu aralıktan uzatıp sülüyü havalandırması ve değneği çekip vurması ile olurdu ki bu şekle "Bacak arası" üçüncü şekil, yan durup eğilerek ve arkadan uzatılan değnekle sülüyü kaldırıp vurmak şeklinde olurdu ki bu şekle de "Yan tuluk" denir. Dördüncü şekil, değnek tutulan elin, kulağı tutan ve diğer elin arasından geçirilerek ve sülüyü o şekilde kaldırıp vurmak şeklinde olur ki, buna da "Aşomini” denir. Oyun daha önce belirlenmiş bitme sayısını ilk yapan ekip tarafından kazanılmış olur. Kazanan ekip, kaybeden ekipteki oyuncuları kendi aralarında paylasır.

Yapılan eşlemeden sonra "Gaggılamak" faslına geçilir. Gaggılama, kaybeden oyuncunun gözünü bağlamak, belinden tutup döndürmek ve istikametini kaybettiğinden emin olup başka bir yere bırakmak suretiyle başlar. Eline verilen değnekle, kadı taşlarını bulması istenir. Bu arada oyun arkadaşları, ellerine aldıkları taşları birbirlerine vurarak "Sesime gel sesime, kargalar kona fesine" şeklinde bağırarak kadı taşlarının bulunduğu yeri, ses vermek suretiyle gaggılanan oyuncuya anlatmaya çalışır. Bu durum, gaggılanan oyuncunun kadı taşlarını bulmasına kadar devam eder.

Eğer önceden anlaşılmışsa kazanan oyuncu, kaybeden oyuncunun sırtına binerek belirli bir mesafeye kadar kendisini taşımasını ister. Gaggılamak da bu şekilde olur. Taraflar tespit edilirken fazla gelen oyuncu olursa veya oynayacak oyuncu, çok iyi bir oyuncu olup, herhangi bir tarafa girdiğinde oyunun dengesini bozacak şekilde ise bu oyuncu "Orta kadı" tabir edilen oyuncu olur. Orta kadı olan oyuncu, oyunda her iki taraf için oynar fakat gaggılama-ya karışmaz. Gaggılamak, oyunda ses çıkarmaya verilen addır (Doğan,2010: 104).

2.56. Tura oyunu: Özellikle büyük çocuklar tarafından oynanır. Çünkü genelde can yakıcı oyundur. Oyuncular, bir halka şeklinde oturur. Bir atkı veya büyük bir mendilin iki ucundan birer kişi tutar ve tersi yönlere bükmeye başlarlar. Böylece mendil kıvrılır ve sertleşir. Kıvırma işi bittikten sonra uçları düğümlenir. Bu malzemeye 'tura' adı verilir. Oyuncular, ellerinde küçük bir para veya yüzük saklayarak birbirlerine uzatırlar, bulmalarını isterler. Yüzüğü en son bulan, ebe olur. 
Ebe, halkanın ortasına girer. Tüm halkayı dolaşır. Bu esnada, elindeki bozuk parayı gizlice birine verir. Sonra ayakta olan oyunculardan birisinin arkasinda durur ve ona tuğra ile vurur. Vurduğu kişiye, "Yüzük kimde?" diye sorar. Oyuncu etrafına bakar, oyuncuların yüzlerine bakar ve paranın kimde olduğunu tahmin etmeye çalışır. Eğer bilirse turayla bir daha sırtına vurur ve bozuk parayı ona verir. Bilen kişi ebe olur. Bilemezse bu sefer de ebe, bilemeyenin gösterdiği oyuncunun arkasına gider. Onun sırtına vurur ve "Söyle bakayım, bozuk para kimde?" der. Para bulunana kadar oyun böylece devam eder (KK: $3)$.

2.57. Uzun Eşek Oyunu: Uzun Eşek oyunu, çocuklar tarafından açık alanlarda oynanan bir oyundur. Oyuna başlamadan önce oyuncular, iki guruba ayrılır. Oyunculardan bir tanesi ebe olur. Gruplar arası kura çekilir. Kurayı kazanan oyuncu grubu üstte, kaybeden oyuncu grubu altta olur. Kaybedenler, ebenin paçasının altına kafalarını sokarlar ve diğer oyuncular da birbirlerine aynı şekilde sokulurlar. İlk oyuncu, koşarak atlar. Diğer oyuncular da aynı şekilde atlarlar. Atlayan oyuncuların ayaklarının yere değmemesi gerekir. Değerlerse oyun sirası diğerlerine geçer.

Tüm oyuncular eşeğe bindikten sonra ilk atlayan oyuncu, ebeye 1'den 10'a kadar bir sayı söyler. Alttaki oyunculardan en arkadaki, sayıyı üç hak kullanarak tahmin eder. Eğer bilirse, bu sefer diğer altta olan oyuncular yukarı çıkma hakkı elde etmiş olurlar. Bilemezlerse diğer grup yine atlar. En başta atlayan oyuncu, altında duran oyuncuya parmağıyla bir veya iki işareti yapar. Oyunun en sonunda altta olan oyuncuya, “Tek mi, çift mi?" diye sorar. Üstteki oyuncunun parmaklarını tek mi, çift mi yaptı̆̆ını en sonda bulunan alttaki bilirse, o grup oyuncuları üste çıkma hakkı kazanmış olurlar (KK: 3, 7).

2.58. Ụ̈ Taş Oyunu: Bu oyun, dokuz taş oyununda olduğu gibi iki kişiyle oynanan bir oyundur. Oyuncuların ikisinde de üçer adet taş bulunur. Oyuncular, ellerindeki taşları birer birer sırasıyla çizgilerin kesiştiği yerlere yerleştirirler. Oyuncular hem rakip oyuncunun taşlarını aynı hizaya getirmesine engel olurlar, hem de aynı zamanda kendileri üç taşlarını aynı hizada sıralamanın mücadelesini verirler. Birbirlerinin taşının üstünden atlayamazlar. Bir hamlede bir kesişme çizgisinin üzerine gelirler. Üç taşını aynı hizada ve üç farklı noktaya getiren oyuncu oyunu kazanmış sayılır (KK: 6,9).

2.59. Yă Satarım Bal Satarım: Açık alanlarda oynanan bir oyundur. Oyuncu sınırlaması yoktur. Oyuna başlamadan önce oyuncular ebeyi belirlerler. Ebe belirlendikten sonra oyuncular, çember şeklini alıp çömelirler. Ebe, eline mendili alıp zıplayarak "Yağ satarım, bal satarım, ustam ölmüş ben satarım. Ustamın kürkü sarıdır. Satsam otuz liradır. Zambak, zumbak arkana, önüne iyi bak." diyerek ve sekerek elindeki mendili, çömelen oyunculardan birisinin arkasına bırakıp koşmaya başlar. 
Arkasına mendil bırakılan oyuncu, mendili hemen eline alır ve kaçan oyuncuyu kovalamaya başlar. Kaçan oyuncu, kovalayan oyuncunun yerine, kendisini kovalayana yakalanmadan oturmak zorundadır. Yakalanırsa yeniden ebe olur. Eğer yakalanmadan oturmayı başarabilirse ebe olmaktan kurtulur. Kovalayan oyuncu ebe olur (KK: 10).

2.60. Yakalamacılık: Genellikle iki kişi arasında oynanır. Oyunculardan biri ebedir. Diğer oyuncu kaçar. Ebe, kaçan oyuncuyu yakalamaya çalışır.

Yakaladığı zaman, ebe değişir. Diğer oyuncu ebe olur. Ebe olan oyuncunun elinin diğer oyuncuya değmesi yeterlidir, diğerinin ebe olması için. Bu oyun, daha kalabalık oyuncu grubu ile de oynanabilir. Bu durumda da ebenin eli ilk olarak kime değerse o oyuncu ebe olacaktır (KK: 1, 3, 4, 5, 8, 9, 10).

2.61. Yakan Top: Bu oyun, iki grup hâlinde oynanır. Her grubun üyesi, iki kişiden az olamaz. Sayı çoğaltılabilir. Oyun için bir alan belirlendikten sonra oyuncular iki gruba ayrılır. Plastik topla oynanır. Oyunun içinde ilk olarak hangi takımın oynayacağı, yazı tura şeklinde bir seçme yöntemiyle belirlenir. Mesela metal parayı andıran bir taş yerden alınır. Bir tarafında belirgin bir iz yoksa iz oluşturmak için bir tarafına tükürüldüğü olur. Böylece bir tarafı ıslak, diğer tarafı kuru taş havaya atılarak ilk oyuncu grubu belirlenir. Bazen elde taş saklanır.

Bilen kişinin grubu ortaya geçer. Bilemeyenler ikiye bölünerek iki tarafta durur. Top yardımıyla ortadaki grubu vurmaya çalışır. Ortadakiler topu havada yakalarsa bir 'can' kazanmış olurlar. Bu nedenle top, yere sektirilerek atılmaya çalışılır. Tutulan her can için bir oyuncu alma hakkı vardır. Top değen kişiler, oyundan çıkar. En sona kalan bir kişi için yedi kere atış olur. Bu kişi vurulmazsa tüm oyuncular tekrar oyuna girer, eğer vurulursa sıra, diğer takıma geçer (KK: 2, 3, 5, 6, 9).

2.62. Yazı Tura Oyunu: En az iki kişiyle oynanan bir oyundur. Oyunda metal para kullanılır. Metal paranın yazılı kısmına 'yazı', resimli tarafına 'tura' denir. Metal parayı eline alan oyuncu, diğer oyuncuya; "Yazı mı, tura mı?" diye sorar. Diğer oyuncu, istediğini seçer. Onun seçmediği de diğer oyuncunun olmuş olur. Oyuncu, elindeki parayı havaya atar. Para yere düştüğünde, hangi oyuncunun seçtiği taraf üste gelirse o oyuncu oyunu kazanmış olur (KK: 2, 8).

2.63. Yedi Tuğla Oyunu: Açık alanlarda oynanan bir oyundur. Oyuna başlamadan önce yedi taş veya tuğla parçası bulunur. Bulunan taş veya tuğla parçaları, üst üste dizilir. Yedi, sekiz adım ileriye bir çizgi çizilir. Oyuncular, eşit şekilde iki gruba ayrılırlar. Oyuna ilk başlayacak olan grup, kura veya sayışmaca sonucu belirlenir. Diğer oyuncular, çizginin gerisine geçerler. Kurayı kaybeden grubun oyuncularından birisi, dizilen yedi tuğlanın başında durur. Diğerleri, çizginin gerisinde bekler. Karşı takımdan oyuncular, sırasıyla 
topu ellerine alarak çizgiyi geçmeden, dizili olan tuğlaları devirmek için atış yaparlar. Atış yapan oyuncu vuramazsa sıra, takımın diğer oyuncusuna geçer.

Oyuncuların hiçbirinin tuğlaları deviremediği durumda ise atış yapma sırası, diğer gruba geçer. Eğer tuğlaları devirirlerse, takımın oyuncuları kaçar. Kaledeki oyuncu, topu eline alarak kaçan oyunculara nişan alır. Onlardan birisini vurmaya çalısır. Atıp vuramadığı zaman da kendi grup arkadaşları, topu kaledeki arkadaşlarına atarlar. Bu arada grubun diğer üyeleri, yıkılan tuğlaların yanına gelip onları üst üste dizmekle meşguldürler. Kaledeki oyuncu topu attıgı zaman, diğer oyuncular vurulmadan tuğlaları üst üste dizerlerse oyunu kazanırlar. Tuğlaları dizemeden vurulurlarsa da oyunu kaybetmiş olurlar. Atış sırası, diğer grup oyuncularına geçer. Bu oyunda, el çabukluğu ve hız çok önemlidir (KK: 6, 8).

2.64. Yemek Yeme Yarışması: Oyuncular önlerine, eşit miktarda yemek alırlar. Hangi oyuncu yemeği fazla yerse o oyuncu, yarışmayı kazanmış olur. $\mathrm{Bu}$ oyun, çok farklı yiyeceklerin yenmesi veya içeceklerin içilmesi üzerine kurgulanabilir. Örneğin pekmez veya yoğurt yeme; su veya gazoz içme yarışması. Bu durumda, en can yakıcı oyunlardan birisi, en çok acı biber yenilerek oynanacak oyun olabilir (KK: 2, 5, 7).

2.65. Yumurta Tokuşturma Oyunu: Oyuncu sayısı sınırsızdır. Oyuncular, ikişerli gruplar hâlinde eşleşir, karşılıklı otururlar. Avuçlarına aldıkları yumurtaları sıkıca tutarak, uçlarından birbirlerine vururlar. Çarpışmanın etkisiyle kırılan ya da çatlayan yumurtanın sahibi, oyunu kaybetmiş olur. Bu durumda yumurtasını, rakibine vermek mecburiyetinde kalır (KK: 1, 9).

2.66. Yüzük Oyunu: Genellikle kapalı alanlarda, düğünlerde oynanan bir oyundur. Oyuna başlamadan önce, bir adet tepsi, dokuz adet fincan, bir adet yüzük getirilir. Oyunda en ideal oyuncu sayısı, yedi kişilik iki gruptan oluşan 14 kişidir. Oyuna, hangi grubun başlayacağını belirlemek için, her gruptan birer kişi seçilir. Tepsinin içinde ters olarak duran iki fincandan birinin altına yüzük bırakılır. Karşı gruptan bir oyuncu tepsinin başına gelir ve iki fincandan birini seçip "Bize" der. Eğer yüzüğü bulursa bu sefer diğer grup saklar. O da bulursa diğer grup saklar ve bu durum, boş fincan seçilene kadar devam eder.

Son olarak yüzüğü bulan grup, oyuna başlar. Oyuna başlamadan önce bir sayı belirlenir. Oyuncular, karşı karşıya otururlar. Seyirci grubu da oyuncuların etrafında bulunur. Kurayı kazanan grup; tepsi, fincanları ve yüzüğü alır. Sonra gruptan, bir kişi seçilir. Seçilen oyuncu; tepsi, fincan ve yüzügü alır ve fincanlardan birinin altına saklar. Diğer oyuncular, yüzüğü saklayan oyuncunun üzerini örter. Fincanları, tepsi içinde çeşitli şekillerde dizer. Dokuz fincandan yedisi saklayanın, ikisi arayanındır. Arayan oyuncunun, iki defa "Bi-ze" diye söyleme hakkı vardır. Bunu istediği zaman söyler. Eğer "Bize" söz-cügüunü 
söylemeden once, fincanlardan birini kaldırır ve fincan boş çıarsa saklayan gruba, on sayı yazılır.

Karşı grup, fincanın birine "Bize" derse ve diğerini de kaldırıp yüzük çıkarsa bu sefer, tepsideki fincanlar sayılır. Tepsiyle beraber dokuz sayı, saklayan gruba yazılır. Hiç "Bize" demeyip üç fincan kaldığı zaman yüzük, üçüncü fincanda çıksa bile yine on sayı yazılır. Tepsi, ilk hazırlandığında arayan grubun önüne bırakılır. Saklayan grup hariç, arayan grup ve seyirciler; "Yüzük bunda." diyerek fincanların üzerine işaret koyabilirler. Bu işaret koyma durumuna, "Güman getirme" denir (KK: 3, 4).

2.67. Zeytin Çekirdeği Oyunu: Zeytin çekirdeği oyunu, açık alanlarda oynanan bir oyundur. Oyuna başlamadan önce oyuncular, 'kale' adını verdikleri $5 \mathrm{~cm}$ 'lik bir çukur açarlar. Açılan çukurun beş altı metre kadar uzağına, bir çizgi çizerler ve ellerine aldıkları zeytin çekirdeğini, çizilen çizgiden kaleye doğru atarlar. Burada asıl amaç, çekirdeği kalenin içine ya da yakınına atmaktır. Zeytin çekirdeğini, kalenin içerisine atan oyuncu, birinci olur. Ama birden fazla çekirdek kalenin içine girerse, o oyuncuların hepsi yeniden çizgiden atarlar. Atılan çekirdeklerin yakınlıklarına göre, sıralama belirlenir.

Kimsenin çukura çekirdeğini sokamadığı durumda ise en yakın oyuncu, birinci olur. Birinci olan oyuncu, baş parmağı yardımıyla zeytin çekirdeğini kaleye girdirmeye çalışır. Girdirdiği zaman, çekirdeği alır. İstediği başka bir çekirdeği daha kaleye girdirmeye çalışır. Ancak bu sefer kaleye girdiremezse sıra, ikinci oyuncuya geçer. İkinci oyuncu da aynı şekilde, istediği çekirdeği kaleye girdirmeye çalışır. Oyun bu şekilde devam eder (Doğan, 2010: 63).

\section{Sonuç ve Öneriler}

Oyunlar incelendiğinde oyun malzemesi olarak; bilye, ceviz, değnek, gazoz kapağı, kendir, kibrit, mendil, taş, top, topaç, yumurta, zeytin çekirdeği gibi malzemelerin kullanıldığı görülür. Bu malzemeler sosyal hayat içerisinde kolaylıkla bulunabilecek türdendir. Anlaşılacağ üzere kolayca edinilebilecek bir malzeme, çocuk dünyasında eğlenceli, eğitici ve masrafsız bir oyuna dönüşebilmektedir. Çocuk açısından vaz geçilmez bir oyun aracı olabilmekte, oyun ihtiyacını karşılayabilmektedir.

Oyun çağında olan çocuklar için oyun ihtiyacı, çocuğun diğer tüm ihtiyaçları kadar önem arz etmektedir. Oyun, çocuğun birçok açıdan gelişmesi için hayatında mutlaka olması gereken aktivitedir. Oyun; çocuğu fiziksel, sosyal, kültürel, psikolojik, dil, zihinsel ve psiko-motor açılardan geliştirir, sağlıklı bir birey olarak toplum içerisinde var eder. Bu nedenle oyunlar ve oyunun kazandıracakları kesinlikle göz ardı edilmemeli, çocuğun hayatında oyunun yeterince yer alması için imkânlar, seferber edilmelidir. 
Çocuklar, oyunda tüm bedenleriyle aktif hâldedirler. Oyuna, her şekilde dâhil durumdadırlar. Oyun oynayan bir çocuğun, dış dünya ile irtibatını tamamen kesip kendisini oyuna vermesi bunun kanıtıdır.

Çocukların, oyundan uzak şekilde büyümesi; neşeden, eğlenceden, eleştirel düşünceden, bireysellikten, sosyalleşmeden ve üreticilikten uzak, kendisini gerçekleştirememiş, ait olduğu toplum içerisinde herhangi bir varlık gösterememiş bireylerin sayısının artması anlamına gelmektedir. Bu nedenle oyunun, çocuğun gelişimine katkısı inkâr edilemeyecek kadar fazladır.

Günümüzde ne yazık ki çocuk oyunları, teknolojiye kurban verilmiş durumdadır. Oyun deyince akla artık bilgisayar oyunları gelmekte, çocuklar zamanlarının çok ciddi bir bölümünü, bilgisayar başında bu oyunların içerisinde ya da televizyon karşısında geçirmektedir. Her şeyin oranında olmasının en verimli olması gibi içinde yaşadığımız çağın gereği olarak kabul edilebilecek sanal oyunların da belirli süre harcanarak oynanmasında belki bir sakınca yoktur. Ancak şu da unutulmamalıdır ki bu oyunların çocuklara kazandıracakları, geleneksel oyunların kazandıracakları yanında çok kısıtlıdır. İşte bu bilinçle hangi oyun türüne ne kadar zaman harcanacağı, gerekirse ebeveynler tarafından tespit edilmeli, çocuk bu doğrultuda yönlendirilmelidir. Teknolojiye kurban vermemek ve daha sağlıklı nesiller elde etmek adına başta ebeveynler, sonra kurumlar ve sivil toplum kuruluşları gereğince çalışmalar yapmalı, geleneksel oyunların yok olup gitmesine müsaade edilmemelidir.

$\mathrm{Bu}$ çalışma, Malatya ili merkezinde oynanan çocuk oyunlarının tespiti ve bu oyunların çocuk eğitimine katkısını ortaya koymak amacıyla yapılmıştır. Bu doğrultuda yapılmış akademik çalışmaların kısıtlılığ çalışmayı zorunlu kılmıştır. Sonuçta oyunun, çocuğun gelişiminde hayati öneme sahip olduğu bilgisine ulaşılmıştır.

Çünkü çocuklar kendilerini, en iyi şekilde oyunla geliştirir ve ifade ederler. Çocuğun sevincini, neşesini, korkusunu, endişesini, üzüntüsünü, merakını, kaygılarını, kızgınlığını kısacası bütün iç dünyasını oyun esnasında izleyip kavramak mümkündür. Ayrıca oyun; çocuğun fiziksel, sosyal, kültürel, psikolojik, dilsel, zihinsel ve psiko-motor gelişimi bakımından yiyecek, içecek gibi fizyolojik ihtiyaçları kadar önemli bir ihtiyaçtır.

\section{KAYNAKÇA}

\section{Yazılı Kaynaklar}

Bacanlı, Hasan (2015); Eğitim Psikolojisi, Pegem Yayınları, Ankara.

Boratav, Pertev Naili (2016); 100 Soruda Türk Folkloru, Bilgesu Yayınları, Ankara.

Doğan, Abdullah (2010); Geleneksel Mahalli Çocuk Oyunları Malatya İli Battalgazi İlçesi Tezi).

Örneği, (Niğde Üniversitesi Sosyal Bilimler Enstitüsü Yayımlanmamış Yüksek Lisans 


\section{YASEMIN KATI}

Erol, Sedat (2019); Yabancı Dil Olarak Türkçe Öğretiminde Eğitsel Oyunların Kullanımı, (İnönü Üniversitesi Eğitim Bilimleri Enstitüsü Yayımlanmamış Doktora Tezi).

Göncü, Artin (2005); Oyunun Çocuğun Hayatındaki Yeri, Gelişim ve Öğrenme,

Nobel Yayınları, Ankara.

Gül, Özgür (2012); Oyun Ve Hareket Temelli Büyük Kas Beceri Eğitim Programlarının 4-5 Yaş Çocukların Büyük Kas Becerilerine Etkisinin Karşılaştırılması, (Konya Selçuk Üniversitesi Eğitim Bilimleri Enstitüsü.Yayımlanmamış Doktora Tezi).

Kantarcıŏlu, Selçuk (1992); Anaokulunda Eğitim, Millî Eğitim Basımevi, İstanbul.

Nutku, Özdemir (1998); Oyun, Çocuk, Tiyatro, 1.bs., Özgür Yayınları, İstanbul.

Türk Dil Kurumu (1998); Türkçe Sözlük. 9. bs. TDK, Ankara.

Oğuzkan, Ferhan (2001); Çocuk Edebiyatı, Anı Yayıncılık, Ankara.

Örnek, Sedat Veyis (2015); Geleneksel Kültürümüzde Çocuk, Bilgesu Yayınları, Ankara.

Özbakır, İbrahim (2009); Geleneksel Türk Çocuk Oyunlarında Fonksiyonel Oyuncu "Ebe", Uluslararası Sosyal Araştırmalar Dergisi, Winter (2/6).

Özhan, Mevlüt (1997); Türkiye'de Çocuk Oyunları Kültürü, Feryal Yayınları, Ankara.

Senemoğlu, Nuray (2009); Gelişim Öğrenme ve Ögrretim, Kuramdan Uygulamaya, Pegem Yayınları, Ankara.

Uluğ, Ormanlığlu, Mücella (2007); Niçin Oyun? Çocuğun Gelişiminde ve Çocuğu Tanımada Oyunun Önemi, Anfora Yayınları, İstanbul.

Yavuzer, Haluk (2000); Çocuk Psikolojisi, Remzi Kitapevi, İstanbul.

Yeşilyaprak, Binnur (2006); Gelişim ve Öğrenme Psikolojisi, Pegem A Yayıncılık, Ankara.

\section{Sözlü Kaynaklar}

KK. 1: R. Kaya, 1964, Fırat Mahallesi doğumlu, ev hanımı, okur - yazar.

KK. 2: C. Bozkurt, 1954, Melekbaba mahallesi doğumlu, ev hanımı, okur- yazar.

KK. 3: M. Katı, 1954, Yeşilyurt doğumlu, emekli, okur-yazar.

KK. 4: G. Altın, 1958, Orduzu Mahallesi doğumlu, ev hanımı, okur - yazar.

KK. 5: H. Ürün, 1957, Tecde Mahallesi doğumlu, ev hanımı, okur - yazar.

KK. 6: Ş. Katı, 1956, Karakavak Mahallesi doğumlu, ev hanımı, okur - yazar.

KK.7: G. Gür, 1971, Konak Kasabası doğumlu, ev hanımı, okur - yazar.

KK. 8: H. Bozkurt, 1952, Melekbaba mahallesi doğumlu, emekli, okur-yazar.

KK. 9: E. Kutlu, 1956, Çilesiz Mahallesi doğumlu, ev hanımı, okur - yazar.

KK. 10: İ. Yılmaz, 1945, Yeşilyurt Topsöğüt Mahallesi doğumlu, çiftçi, okur - yazar değil. 